\title{
Teplota vzduchu a srážky na meteorologické stanici Bučnice v povodí horní Metuje
}

\section{PAVEL TREML}

Klíčová slova: teplota vzduchu - srážky - denní chod teploty vzduchu - roční chod teploty vzduchu denní chod srážek - roční chod srážek - metoda součtových řad - Bučnice

\section{SOUHRN}

Článek se zabývá analýzou časových řad teploty vzduchu a srážek na meteorologické stanici Bučnice ve východních Čechách, kterou provozuje Výzkumný ústav vodohospodárský T. G. Masaryka. Je hodnocen průběh ročního a denního chodu obou veličin a analyzovány trendy obou veličin. Byla provedena typizace teploty vzduchu na základě rychlosti jejího růstu vůči maximu a minimu teploty.

\section{ÚVOD}

Výzkumný ústav vodohospodářský T. G. Masaryka, v. v. i., provádí dlouhodobě kromě hydrologických měření i meteorologická pozorování, a to na třech místech České republiky - ve východních Čechách v povodí horní Metuje (stanice Bučnice), v jižních Čechách (stanice Hlasivo - 10 km SV od Tábora) a v areálu Vúv TGM v Praze-Podbabě.

$\checkmark$ tomto př́spěvku budou predstaveny nejzajímavější výsledky z měření z jednoho z těchto míst - meteorologické stanice Bučnice.

Meteorologická stanice Bučnice leží na hranici katastrálních území Teplic nad Metují (do kterého zároveň patří) a Adršpachu, jehož místní část Bučnice se nachází približně $100 \mathrm{~m}$ od areálu meteorologické stanice (obr. 1). Samotný Adršpach je necelé $2 \mathrm{~km}$ SZZ. GPS souřadnice stanice jsou 50³6 37.356" s. š. a $16^{\circ} 8^{\prime} 57.635^{\prime \prime}$ v. d.

Meteorologická stanice Bučnice leží v údolí nedaleko soutoku Bučnice s Metují, je obklopena výrazně vyšším terénem (ve všech směrech s výjimkou SV převýšení o 50 až 60 m na 300 m, na SV nejprve mírný nárůst nadmořské výšky, poté větší převýšení, celkově 90 m na 1,1km, největší terénní překážku tvoři vrchol Lada 900 m SSZ od stanice s prevýšením 130 m). Tento faktor je spolu s nadmořskou výškou 493 m a okolním zalesněným terénem hlavním klimatotvorným faktorem. Na stanici bývají v zimě měřeny jedny z nejnižších teplot $v$ republice.

Údaje z meteorologické stanice Bučnice Ize nalézt pod více názvy. Oficiální název stanice je Bučnice podle nedaleké místní části a potoka, který zde protéká. Název Bučnice je používán Výzkumným ústavem vodohospodářským T. G. Masaryka, v. v. i., a takto je uváděn ve všech studiích. Stanice je zapojena rovněž do pozorovací sítě Českého hydrometeorologického ústavu - tam je ale uvedena pod označením Adršpach-Horní Adršpach (H1ADRS01). Měření Ize sledovat online na adrese: http://portal.chmi.cz/files/portal/docs/poboc/OS/KW/ Captor/tmp/DMULTI-H1ADRS01.gif.

Meteorologická pozorování byla pravděpodobně zahájena $\vee 60$. letech 20. století, avšak data jsou k dispozici až od 70. let 20. století. Dne 20. listopadu 1998 začalo automatické měření veličin po 15 minutách, od 25. 3. 2010 se přešlo na měření každých 10 minut.

$\checkmark$ tomto príspěvku budou vyhodnoceny korigované měřené údaje ze 17letého období 1999-2015, z něhož byly k dispozici jak údaje pro možné hodnocení dlouhodobějšího časového vývoje (sezonní, roční, měsíční změny), tak i pro možné hodnocení mezidenních změn. Roční odvozené charakteristiky (průměr, minimum, maximum, kvantily) jsou odvozeny z ročních prưměrů (tzn. ze 17 ročních hodnot), měsiční charakteristiky z měsíčních průměrů odpovídajících si měsíců (tzn. např. průměrná červencová teplota z 17 průměrných červencových teplot), denní charakteristiky z denních hodnot.

Kromě teplot vzduchu a srážek se na Bučnici měří i směr a rychlost větru, délka trvání slunečního svitu, radiace a relativní vlhkost vzduchu. Údaje o větru jsou ovlivněny polohou stanice, délka slunečního svitu nebyla v letech 2005-2009 měřena správně.

Fyzicko-geografickou charakteristiku oblasti a analýzu hydrologické bilance Ize nalézt v publikaci [1].

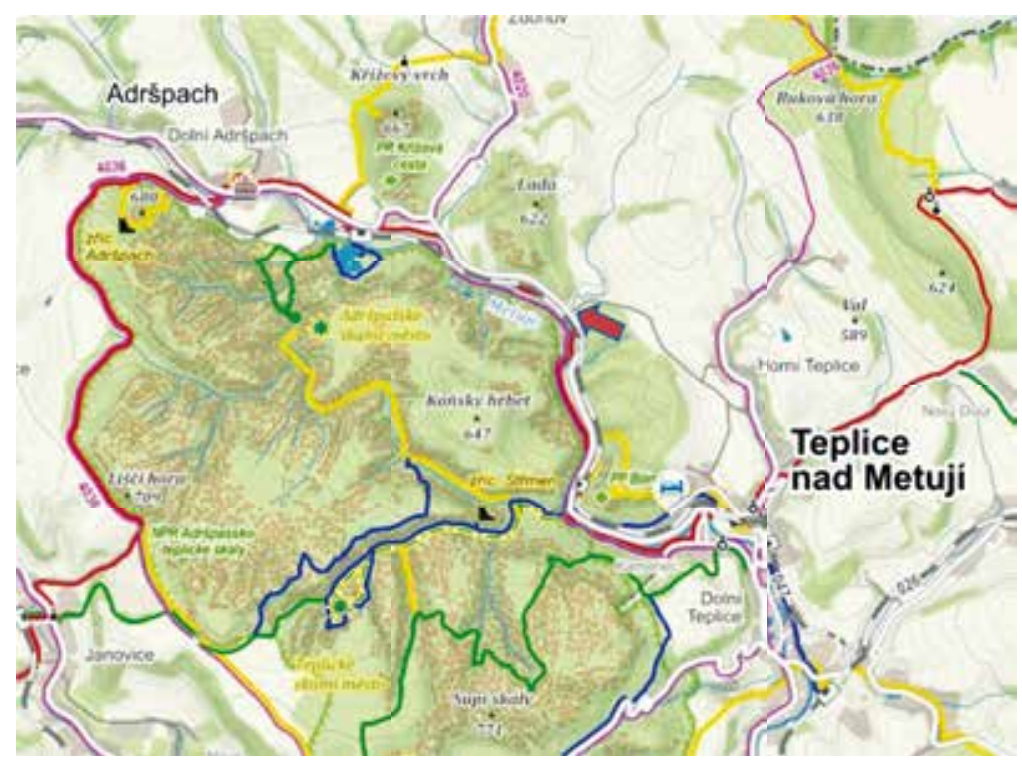

Obr. 1. Poloha stanice Bučnice (zdroj podkladové mapy: mapy.cz) Fig. 1. Location of the Bučnice meteorological station 


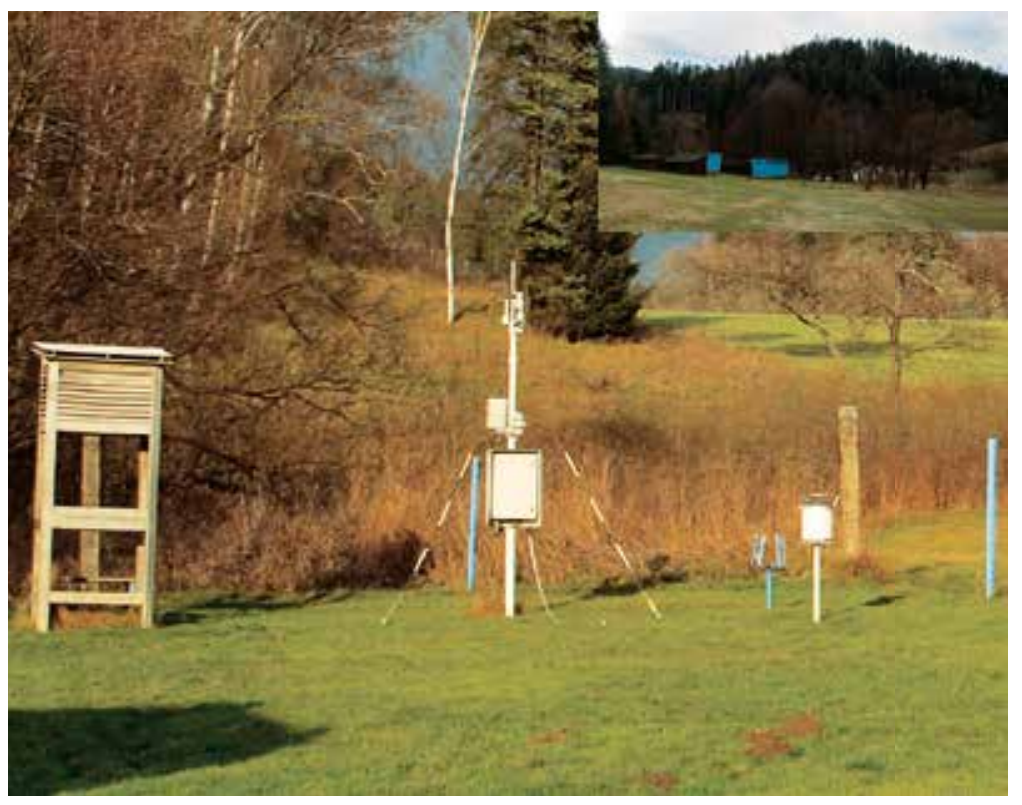

Obr. 2. Meteorologická stanice Bučnice

Fig. 2. The Bučnice meteorological station

\section{TEPLOTA VZDUCHU}

\section{Trendy v denních, měsíčních a ročních teplotách}

Průměrná roční teplota vzduchu je $6,46^{\circ} \mathrm{C}$ (obr. 3), nejnižší $5,4^{\circ} \mathrm{C}$ z roku 2010 (obr. 5), nejvyšší 7,8 ${ }^{\circ} \mathrm{C}$ z roku 2014 (obr. 4). Za sledované období 17 let (1999-2015) vzrostla průměrná teplota $00,68^{\circ} \mathrm{C}$, tzn. v průměru $00,04^{\circ} \mathrm{C}$ za rok. Nejchladnějším měsícem byl leden $2006 \mathrm{~s}$ prüměrnou teplotou $-9,4^{\circ} \mathrm{C}$, nejteplejší červenec 2006 s teplotou $18,4^{\circ} \mathrm{C}$. Leden 2006 byl měsícem i s největší zápornou odchylkou teploty od prüměru $-6,9^{\circ} \mathrm{C}$ (obr. 31), naopak leden 2007 byl nejteplejší, s kladnou teplotní odchylkou $5,2^{\circ} \mathrm{C}$. Nejteplejším měsícem je červenec $s$ průměrnou teplotou $16,1^{\circ} \mathrm{C}$, nejchladnější leden s průměrnou teplotou $-3,1^{\circ} \mathrm{C}$. Významné kvantily pro jednotlivé měsíce jsou znázorněny na obr. 9.

Absolutně nejnižší teplota $-31,5^{\circ} \mathrm{C}$ byla naměřena 3. 2. 2012 v 6:30 hodin, nejvyšší teplota $34,4^{\circ} \mathrm{C}$ byla změřena 8. 8. 2015 v 13:10 hodin. Nejnižší prưměrná denní teplota $-24,5^{\circ} \mathrm{C}$ byla naměřena 3. 2. 2012 (tzn. ve stejný den jako absolutně nejnižší teplota), nejvyšší denní průměrná teplota $23,4^{\circ} \mathrm{C}$ byla změřena 8. 8. 2013. Hodnoty nejvyšších teplot vzduchu se pozvolna zvyšují (obr. 4, tabulka 1), přičemž oteplování odpovídá i nárůst počtu charakteristických dnů s kladnou teplotou - nejvíce se projevuje u počtu dní s vyšší teplotou (tabulka 2 až 4, obr. 6). U počtu dnů s charakteristickou zápornou teplotou vzduchu (tabulka 2 až 4, obr. 7) převažoval do roku 2006 vzestup počtu dnů se zápornou teplotou, $v$ následném období pak dochází ke značné variabilitě počtu chladnějších a teplejších dnů, tomu odpovídá i nejprve se snižující minimální hodnota teploty vzduchu v roce a následné výrazné meziroční kolísání minimální roční teploty vzduchu. Podrobnější vyhodnocení vývoje počtu vybraných charakteristických teplot $v$ jednotlivých letech je uvedeno $v$ tabulkách 2 až 4, $\checkmark$ tabulce 1 jsou pak roční extrémy.

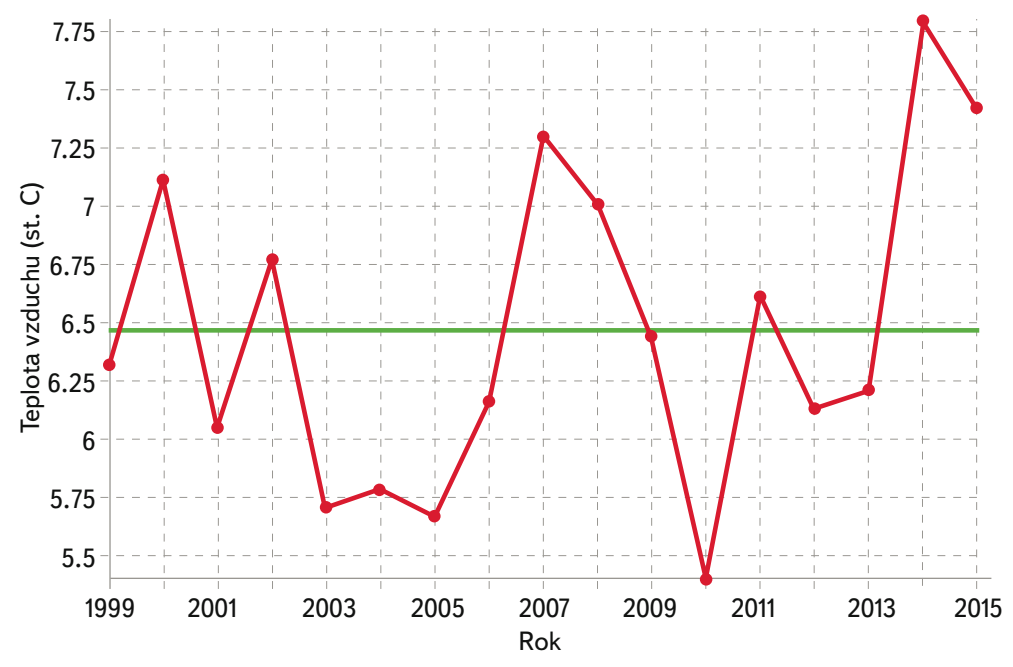

Obr. 3. Průměrná roční teplota vzduchu v jednotlivých letech (zeleně vyznačen průměr za celé období)

Fig. 3. Average annual air temperature

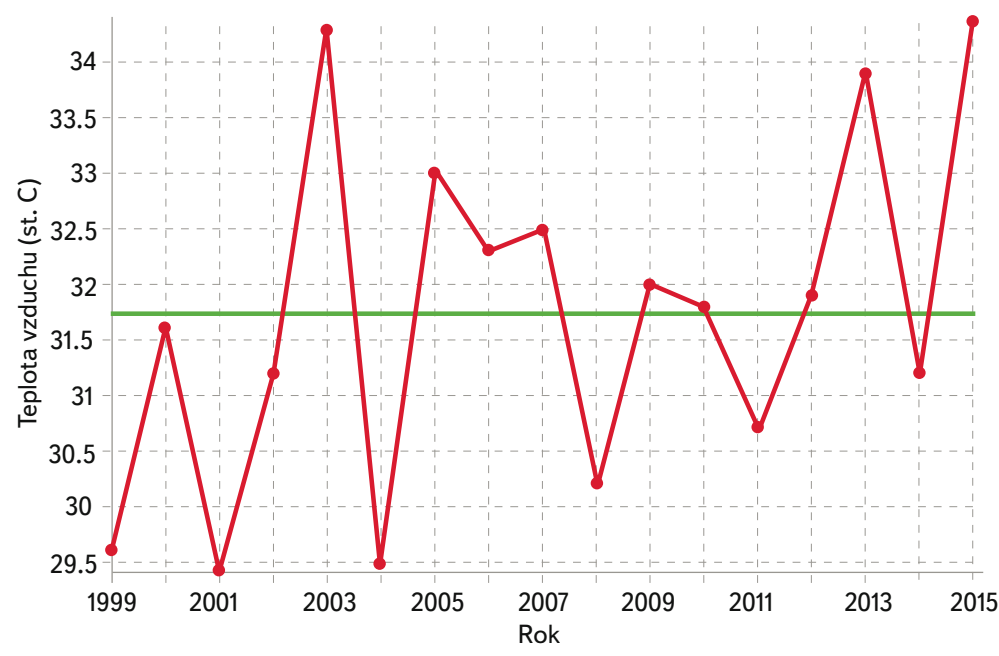

Obr. 4. Roční maxima teploty vzduchu v jednotlivých letech (zeleně vyznačen prưměr za celé období)

Fig. 4. Maximum annual air temperature

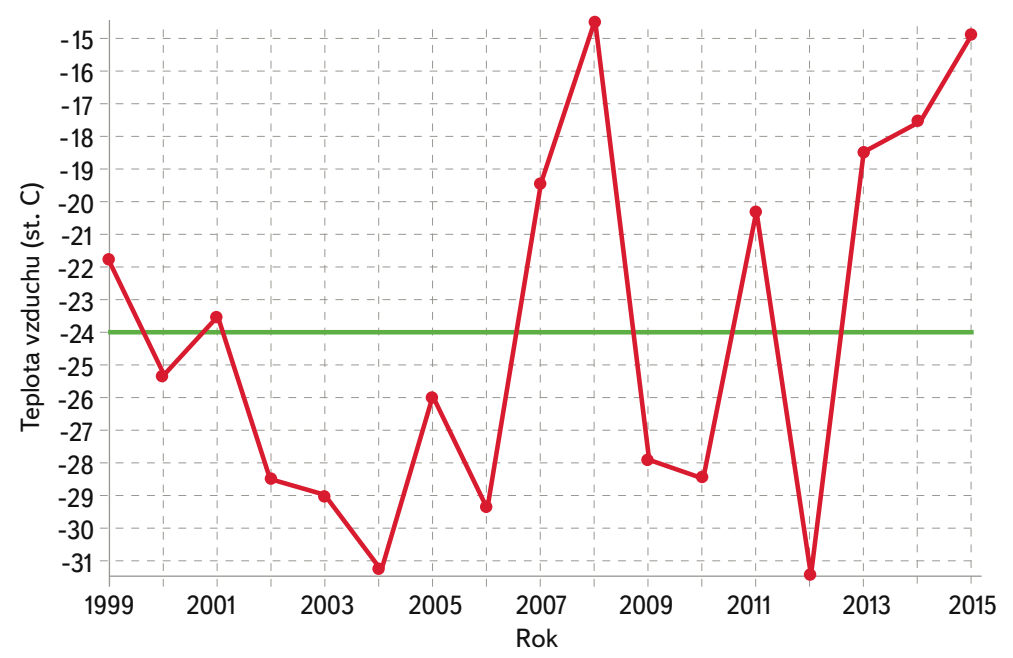

Obr. 5. Roční minima teploty vzduchu v jednotlivých letech (zeleně vyznačen průměr za celé období)

Fig. 5. Minimum annual air temperature 
Tabulka 1. Extrémy teploty v jednotlivých letech

Table 1. Extremes in the air temperature

\begin{tabular}{lcccc}
\hline Rok & $\begin{array}{c}\text { Minimální } \\
\text { teplota }\end{array}$ & $\begin{array}{c}\text { Maximální } \\
\text { teplota }\end{array}$ & $\begin{array}{c}\text { Průměrná } \\
\text { denní } \\
\text { teplota }\end{array}$ & $\begin{array}{c}\text { Medián } \\
\text { denní } \\
\text { teploty }\end{array}$ \\
\hline 1999 & $-21,8$ & 29,6 & 6,3 & 6,5 \\
\hline 2000 & $-25,3$ & 31,6 & 7,1 & 8,0 \\
\hline 2001 & $-23,5$ & 29,4 & 6,1 & 7,4 \\
\hline 2002 & $-28,5$ & 31,2 & 6,8 & 6,5 \\
\hline 2003 & $-29,0$ & 34,3 & 5,7 & 5,7 \\
\hline 2004 & $-31,3$ & 29,5 & 5,8 & 6,9 \\
\hline 2005 & $-26,0$ & 33,0 & 5,7 & 5,8 \\
\hline 2006 & $-29,4$ & 32,3 & 6,2 & 7,8 \\
\hline 2007 & $-19,4$ & 32,5 & 7,3 & 6,7 \\
\hline 2008 & $-14,4$ & 30,2 & 7,0 & 6,6 \\
\hline 2009 & $-27,9$ & 32,0 & 6,4 & 6,9 \\
\hline
\end{tabular}

\begin{tabular}{lcccc}
\hline Rok & $\begin{array}{c}\text { Minimální } \\
\text { teplota }\end{array}$ & $\begin{array}{c}\text { Maximální } \\
\text { teplota }\end{array}$ & $\begin{array}{c}\text { Průměrná } \\
\text { denní } \\
\text { teplota }\end{array}$ & $\begin{array}{c}\text { Medián } \\
\text { denní } \\
\text { teploty }\end{array}$ \\
\hline 2010 & $-28,5$ & 31,8 & 5,4 & 6,5 \\
\hline 2011 & $-20,3$ & 30,7 & 6,6 & 6,8 \\
\hline 2012 & $-31,5$ & 31,9 & 6,1 & 6,1 \\
\hline 2013 & $-18,5$ & 33,9 & 6,2 & 7,0 \\
\hline 2014 & $-17,5$ & 31,2 & 7,8 & 8,2 \\
\hline 2015 & $-14,8$ & 34,4 & 7,4 & 7,1 \\
\hline Průměr & $-24,0$ & 31,7 & 6,5 & 6,8 \\
\hline Minimum & $-31,5$ & 29,4 & 5,4 & 5,7 \\
\hline Maximum & $-14,4$ & 34,4 & 7,8 & 8,2 \\
\hline Medián & $-25,3$ & 31,8 & 6,3 & 6,8 \\
\hline
\end{tabular}

Tabulka 2. Počet dni s charakteristickou prüměrnou denní teplotou v jednotlivých letech Table 2. Number of days with the average characteristic temperature

\begin{tabular}{|c|c|c|c|c|c|c|c|}
\hline Rok & $\begin{array}{c}\text { Nad } \\
20\end{array}$ & $\begin{array}{c}\text { Nad } \\
15\end{array}$ & $\begin{array}{c}\text { Nad } \\
10\end{array}$ & $\begin{array}{c}\text { Nad } \\
5\end{array}$ & $\begin{array}{c}\text { Pod } \\
0\end{array}$ & $\begin{array}{c}\text { Pod } \\
-5\end{array}$ & $\begin{array}{c}\text { Pod } \\
-10\end{array}$ \\
\hline 1999 & 2 & 40 & 139 & 207 & 87 & 19 & 4 \\
\hline 2000 & 3 & 42 & 142 & 221 & 64 & 17 & 4 \\
\hline 2001 & 2 & 53 & 137 & 199 & 101 & 24 & 6 \\
\hline 2002 & 5 & 67 & 141 & 208 & 65 & 30 & 10 \\
\hline 2003 & 4 & 63 & 138 & 190 & 100 & 38 & 19 \\
\hline 2004 & 1 & 40 & 131 & 209 & 91 & 32 & 8 \\
\hline 2005 & 3 & 57 & 128 & 197 & 97 & 38 & 8 \\
\hline 2006 & 11 & 55 & 141 & 223 & 89 & 41 & 21 \\
\hline 2007 & 4 & 65 & 127 & 208 & 42 & 11 & 1 \\
\hline 2008 & 1 & 58 & 120 & 215 & 53 & 10 & 0 \\
\hline 2009 & 1 & 48 & 139 & 215 & 67 & 28 & 12 \\
\hline 2010 & 8 & 53 & 132 & 204 & 99 & 54 & 22 \\
\hline 2011 & 1 & 61 & 142 & 206 & 73 & 19 & 11 \\
\hline 2012 & 9 & 63 & 137 & 203 & 75 & 31 & 20 \\
\hline 2013 & 10 & 46 & 135 & 200 & 95 & 29 & 0 \\
\hline 2014 & 8 & 51 & 155 & 228 & 36 & 12 & 2 \\
\hline 2015 & 15 & 57 & 128 & 215 & 48 & 5 & 0 \\
\hline Min & 1 & 40 & 120 & 190 & 36 & 5 & 0 \\
\hline Max & 15 & 67 & 155 & 228 & 101 & 54 & 22 \\
\hline Průměr & 5 & 54 & 136 & 209 & 75 & 26 & 9 \\
\hline Medián & 4 & 55 & 137 & 208 & 75 & 28 & 8 \\
\hline
\end{tabular}

Tabulka 3. Počet dnís charakteristickou maximální denníteplotou vjednotlivých letech Table 3. Number of days with the maximal characteristic temperature

\begin{tabular}{|c|c|c|c|c|c|c|c|c|c|}
\hline Rok & $\begin{array}{l}\text { Nad } \\
30^{*}\end{array}$ & $\begin{array}{l}\text { Nad } \\
25^{* *}\end{array}$ & $\begin{array}{l}\text { Nad } \\
20\end{array}$ & $\begin{array}{l}\text { Nad } \\
15\end{array}$ & $\begin{array}{l}\text { Nad } \\
10\end{array}$ & $\begin{array}{l}\text { Nad } \\
5\end{array}$ & $\begin{array}{l}\text { Pod } \\
0^{* * *}\end{array}$ & $\begin{array}{l}\text { Pod } \\
-5\end{array}$ & $\begin{array}{l}\text { Pod } \\
-10^{* * * *}\end{array}$ \\
\hline 1999 & 0 & 16 & 78 & 146 & 198 & 241 & 48 & 8 & 1 \\
\hline 2000 & 3 & 27 & 86 & 139 & 203 & 267 & 29 & 8 & 0 \\
\hline 2001 & 0 & 22 & 67 & 134 & 192 & 238 & 49 & 4 & 1 \\
\hline 2002 & 3 & 33 & 94 & 146 & 197 & 269 & 44 & 12 & 3 \\
\hline 2003 & 6 & 44 & 105 & 159 & 196 & 246 & 50 & 9 & 2 \\
\hline 2004 & 0 & 19 & 68 & 147 & 207 & 249 & 54 & 10 & 2 \\
\hline 2005 & 2 & 23 & 78 & 154 & 204 & 246 & 62 & 8 & 0 \\
\hline 2006 & 9 & 38 & 85 & 156 & 211 & 259 & 58 & 12 & 1 \\
\hline 2007 & 3 & 36 & 87 & 147 & 214 & 272 & 21 & 3 & 0 \\
\hline 2008 & 2 & 29 & 82 & 147 & 202 & 279 & 19 & 1 & 0 \\
\hline 2009 & 2 & 24 & 87 & 162 & 207 & 249 & 45 & 12 & 3 \\
\hline 2010 & 6 & 30 & 65 & 132 & 199 & 253 & 76 & 26 & 3 \\
\hline 2011 & 1 & 29 & 100 & 160 & 211 & 264 & 32 & 6 & 0 \\
\hline 2012 & 2 & 35 & 88 & 156 & 204 & 269 & 39 & 18 & 9 \\
\hline 2013 & 8 & 26 & 80 & 139 & 198 & 243 & 51 & 10 & 0 \\
\hline 2014 & 3 & 29 & 75 & 166 & 226 & 300 & 19 & 7 & 0 \\
\hline 2015 & 16 & 40 & 82 & 150 & 217 & 281 & 16 & 0 & 0 \\
\hline Min & 0 & 16 & 65 & 132 & 192 & 238 & 16 & 0 & 0 \\
\hline Max & 16 & 44 & 105 & 166 & 226 & 300 & 76 & 26 & 9 \\
\hline Průměr & 4 & 29 & 83 & 149 & 205 & 260 & 42 & 9 & 1 \\
\hline Medián & 3 & 29 & 82 & 147 & 204 & 259 & 45 & 8 & 1 \\
\hline
\end{tabular}

Pojmenování dnů: * tropický den, ** letní den, ${ }^{* *}$ ledový den, ${ }^{* * *}$ arktický den 
Tabulka 4. Počet dnís charakteristickou minimální denní teplotou v jednotlivých letech Table 4. Number of days with the minimum characteristic temperature

\begin{tabular}{|c|c|c|c|c|c|c|c|c|c|c|c|}
\hline Rok & Nad 20* & Nad 15 & Nad 10 & Nad 5 & Pod 0** & Pod -5 & Pod -10 & Pod -15 & Pod -20 & Pod -25 & Pod -30 \\
\hline 1999 & 0 & 3 & 34 & 108 & 163 & 57 & 17 & 5 & 4 & 0 & 0 \\
\hline 2000 & 0 & 0 & 22 & 108 & 129 & 40 & 21 & 8 & 2 & 1 & 0 \\
\hline 2001 & 0 & 1 & 35 & 120 & 160 & 75 & 34 & 14 & 5 & 0 & 0 \\
\hline 2002 & 0 & 2 & 35 & 118 & 140 & 54 & 25 & 13 & 5 & 5 & 0 \\
\hline 2003 & 0 & 0 & 18 & 93 & 183 & 87 & 46 & 28 & 13 & 6 & 0 \\
\hline 2004 & 0 & 0 & 19 & 96 & 167 & 76 & 31 & 18 & 7 & 5 & 1 \\
\hline 2005 & 0 & 1 & 26 & 97 & 177 & 80 & 39 & 19 & 8 & 1 & 0 \\
\hline 2006 & 0 & 2 & 34 & 115 & 147 & 74 & 41 & 30 & 13 & 4 & 0 \\
\hline 2007 & 0 & 0 & 29 & 112 & 148 & 47 & 8 & 1 & 0 & 0 & 0 \\
\hline 2008 & 0 & 1 & 17 & 92 & 149 & 45 & 12 & 0 & 0 & 0 & 0 \\
\hline 2009 & 0 & 0 & 32 & 98 & 156 & 58 & 21 & 15 & 5 & 1 & 0 \\
\hline 2010 & 0 & 3 & 38 & 116 & 158 & 93 & 53 & 26 & 12 & 1 & 0 \\
\hline 2011 & 0 & 0 & 34 & 107 & 160 & 70 & 20 & 11 & 1 & 0 & 0 \\
\hline 2012 & 0 & 2 & 30 & 104 & 151 & 70 & 38 & 24 & 14 & 7 & 2 \\
\hline 2013 & 0 & 2 & 30 & 104 & 155 & 60 & 15 & 2 & 0 & 0 & 0 \\
\hline 2014 & 0 & 1 & 40 & 124 & 117 & 46 & 4 & 1 & 0 & 0 & 0 \\
\hline 2015 & 0 & 0 & 34 & 93 & 160 & 45 & 8 & 0 & 0 & 0 & 0 \\
\hline Min & 0 & 0 & 17 & 92 & 117 & 40 & 4 & 0 & 0 & 0 & 0 \\
\hline Max & 0 & 3 & 40 & 124 & 183 & 93 & 53 & 30 & 14 & 7 & 2 \\
\hline Průměr & 0 & 1 & 30 & 106 & 154 & 63 & 25 & 13 & 5 & 2 & 0 \\
\hline Medián & 0 & 1 & 32 & 107 & 156 & 60 & 21 & 13 & 5 & 1 & 0 \\
\hline
\end{tabular}

Pojmenování dnů: * den s tropickou nocí, ** mrazový den

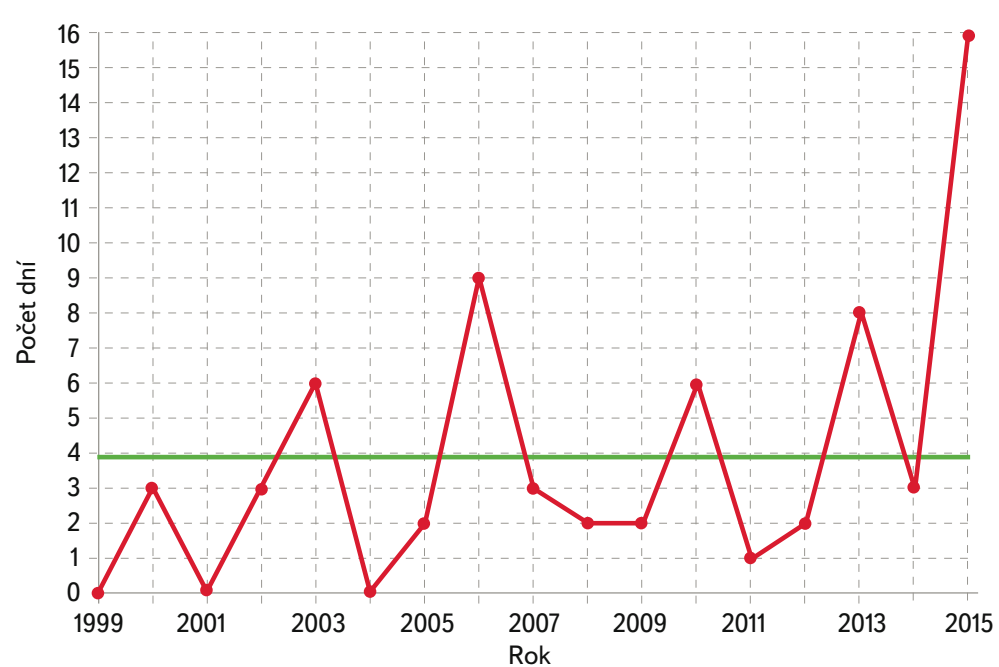

Obr. 6. Počet dnís maximální teplotou nad $30^{\circ} \mathrm{C}$ (tzv. tropických dnů; zeleně vyznačen průmèr za celé období)

Fig. 6. Number of days with the maximal temperature over $30^{\circ} \mathrm{C}$

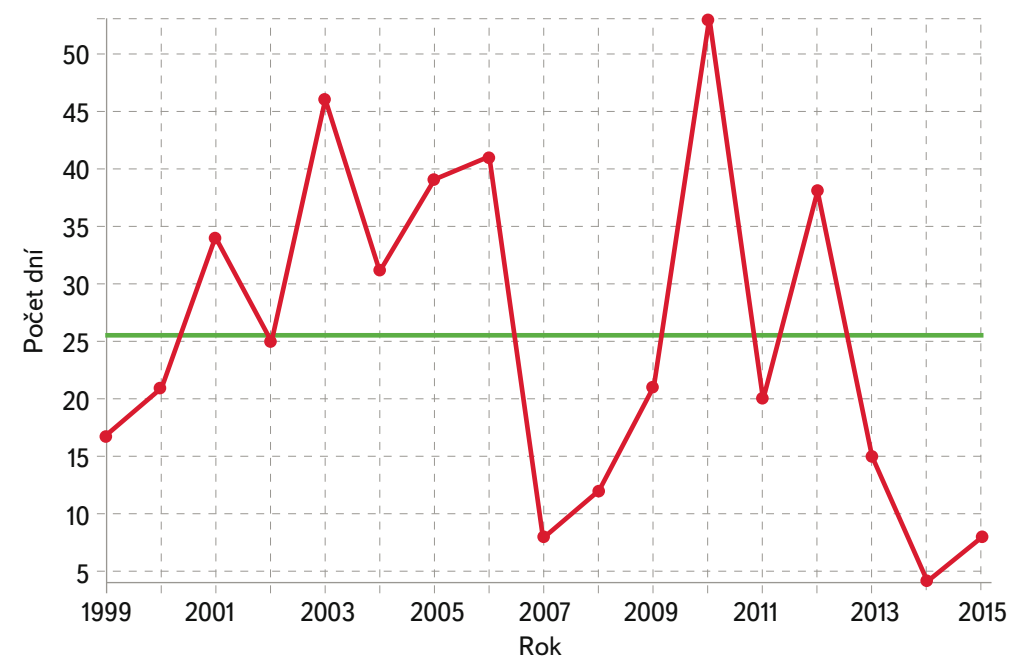

Obr. 7. Počet dní s minimální teplotou pod $-10^{\circ} \mathrm{C}$ (zeleně vyznačen prưměr za celé období)

Fig. 7. Number of days with the minimal temperature below $-10^{\circ} \mathrm{C}$ 


\section{Datum výskytu nejnižší a nejvyšší teploty v roce, období největšího růstu a poklesu teploty, teplotní singularity}

Nejnižší teplota vzduchu byla naměřena nejdřive 8. prosince 2013, nejpozději 27. února 2001, medián hodnot připadá na 24. ledna, průměr na 17. leden (souvisí s prosincovými minimy teplot). Nejvyšší teplota vzduchu byla změřena nejdřive 20. června 2002, nejpozději 26. srpna 2011. Průměrně se vyskytuje kolem 20. července, medián připadá na 21. červenec. Nejčastějším měsícem výskytu ročního maxima teploty je měsíc červenec (53 \% prípadů), následuje měsíc srpen (29\%) a červen (18\%). Roční minimum teploty se nejčastěji vyskytuje v lednu (47\% případů), následuje prosinec (29\%) a únor (24\%).

$\checkmark$ období mezi minimem roční teploty vzduchu a následným maximem roční teploty vzduchu teplota roste a v období mezi maximem roční teploty vzduchu a následným minimem roční teploty vzduchu teplota klesá. Růst i pokles teploty není stejnoměrný. Vyhodnotit změny $v$ ročním chodu teploty vzduchu je možno více způsoby.

Nejjednodušeji je možno analyzovat změny v ročním chodu teploty vzduchu pomocí křivky sestrojené na základě kumulace součtu odchylek teploty vzduchu jednotlivých dnů od ročního průměru príslušného roku za celé období pozorování (obr. 8).

Nejnižší teplota $\vee$ roce $\vee$ tomto prípadě připadá na 24. leden, přičemž je patrný významný propad teploty vzduchu v období mezi 19. lednem a 5. únorem. Nejvyšší teplota vzduchu připadá na 29. červenec, přičemž v nejteplejším období v roce približně mezi 16. červencem a 8 . srpnem nejsou výrazné výkyvy teploty. Na křivce růstu teploty vzduchu dochází k významnějším poklesům teploty oproti průměru v období od 19. do 28. března, mezi 4. a 9. dubnem, následně na počátku května nastává zpomalení růstu teploty, mezi 10. až 14. květnem pak výrazný pokles teploty (označován jako tzv. ledoví muži). Další singularita $v$ chodu teploty nastává po 11. červnu, kdy dochází k dlouhodobějšímu zastavení růstu teploty. V tomto období převládá vlhké Z a SZ proudění, označované nesprávně jako letní evropský monzun, popř. jako Medard. Na sestupné fázi křivky teploty vzduchu je patrné zastavení poklesu teploty na začátku září (2.-12. zárí) a následně v období babího léta (mezi 19. zářím a 7. řijnem). Následně dochází k zastavení poklesu teploty mezi 13. řijnem a 7. listopadem. Krátkodobě dochází k zastavení poklesu teploty ještě mezi 11. a 18. listopadem.

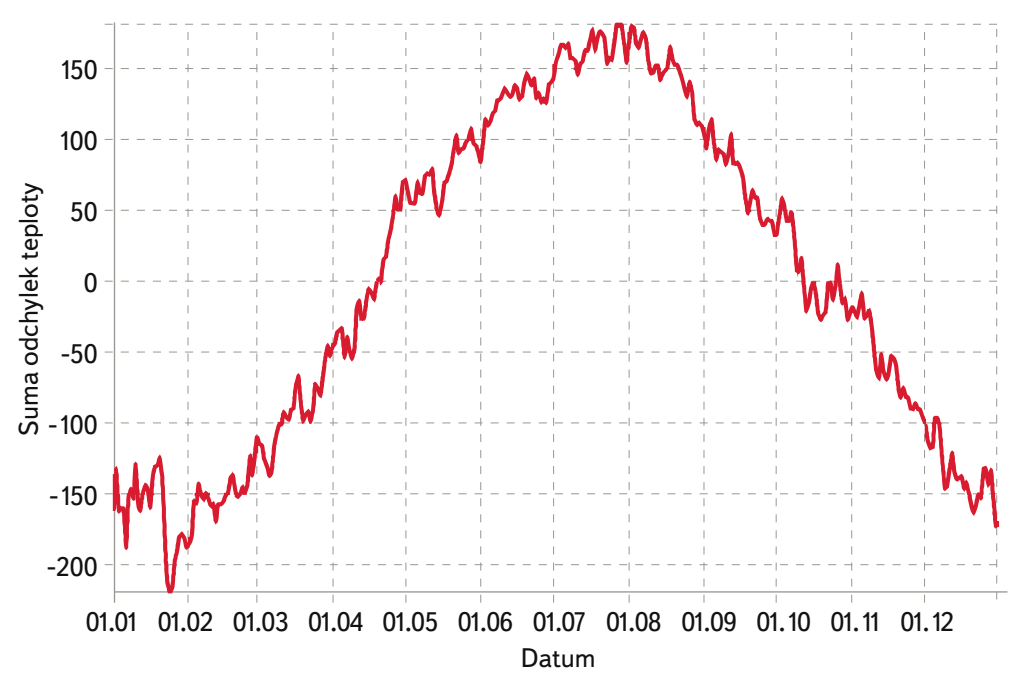

Obr. 8. Průměrný roční chod teploty vzduchu

Fig. 8. Annual air temperature distribution
Za významné singularity v teplotě vzduchu na Bučnici lze označit květnové a červnové ochlazení, babí léto a oteplení od druhé poloviny řijna do začátku listopadu. Ostatní odchylky v teplotě vzduchu jsou méně výrazné, a proto tato období nelze považovat za singularity. Jedná se i o vánoční oblevu, oteplení mezi 26. a 28. prosincem, které je srovnatelné s ostatními teplotními odchylkami v zimě či v jiných částech křivky. Tento poznatek souhlasí i se studií [2], kde autoři studovali výskyt vánoční oblevy na 43 rưzně položených stanicích v období let 1961 až 2008 a žádnou souvislost zde nenalezli.

Další možnou metodou k analýze ročního chodu teploty vzduchu je možnost využití metody součtových řad, která hledá období největšího růstu teploty (NRV) a období největšího poklesu teploty (NRP) na základě kumulovaného součtu mezidenních odchylek teploty vzduchu od průměru. Období NRV je období, v němž teplota vzduchu nejrychleji roste a období NRP je období, $\checkmark$ němž teplota vzduchu nejrychleji klesá. Podrobný popis metody součtových řad je uveden v článku [3].

Podle polohy období NRV a NRP vzhledem k teplotnímu extrému (maximu nebo minimu teploty) Ize provést typizaci extrémů na čtyři typy [4]. Pro označení jednotlivých typů extrémů jsou použita písmena $V$ a $U$, kde písmeno $\checkmark$ označuje rychlý vzestup (resp. pokles) teploty a písmeno $U$ pomalý vzestup (resp. pokles) teploty před nebo po dnu extrému. Pro maximální teplotu jsou definovány následující čtyři typy extrémů:

1. Typ VV - období největšího vzestupu teploty předchází dnu s výskytem nejvyšší teploty v roce a po dnu výskytu nejvyšší teploty v roce následuje období největšího poklesu teploty;

2. Typ Vu - období největšího vzestupu teploty předchází dnu s výskytem nejvyšší teploty v roce, po dnu výskytu nejvyšší teploty v roce nastává období s pozvolným poklesem teploty;

3. Typ UV - nastává pozvolný vzestup teploty až ke dnu s nejvyšší teplotou $v$ roce, po dnu s nejvyšší teplotou $v$ roce následuje rychlý pokles teploty v období největšího poklesu teploty;

4. Typ UU - před dnem výskytu nejvyšší denní teploty v roce nastává pozvolný vzestup teploty a po dnu výskytu nejvyšší denní teploty v roce nastává pozvolný pokles teploty vzduchu.

Obdobná typizace platí i pro minimální teplotu s tím, že se hodnotí poloha výskytu období největšího poklesu pred minimem a období největšího růstu po minimu.

U maximální teploty vzduchu (obr. 11) převládal pozvolný typ UU (všechny prípady), u minima typ, v němž bud’ před, nebo po dni minimální teploty následuje významný pokles teploty vzduchu (82 \%) - ve $41 \%$ prípadů prevládal typ VU, ve 29 \% prípadů typ VV, ve 12 \% prípadů typ UV, pozvolný typ UU nastal v $18 \%$ př́padů. Převaha typu, v němž bud’ před, nebo po dni minimální teploty následuje významný pokles teploty vzduchu, je dán advekcí chladného vzduchu. Ochlazení, které přitom nastává, je velmi výrazné (pokles průměrné denní teploty vzduchu během několika dnů o více než $-10^{\circ} \mathrm{C}$ ). Pokud je pokles teploty před výskytem minima menší nebo vzestup teploty po výskytu minima menší, tak převažuje růst teploty v jiné části roku, navíc období NRV (NRP) trvá déle. Obdobné zastoupení jednotlivých typů extrémů je popsáno i v [4]. 


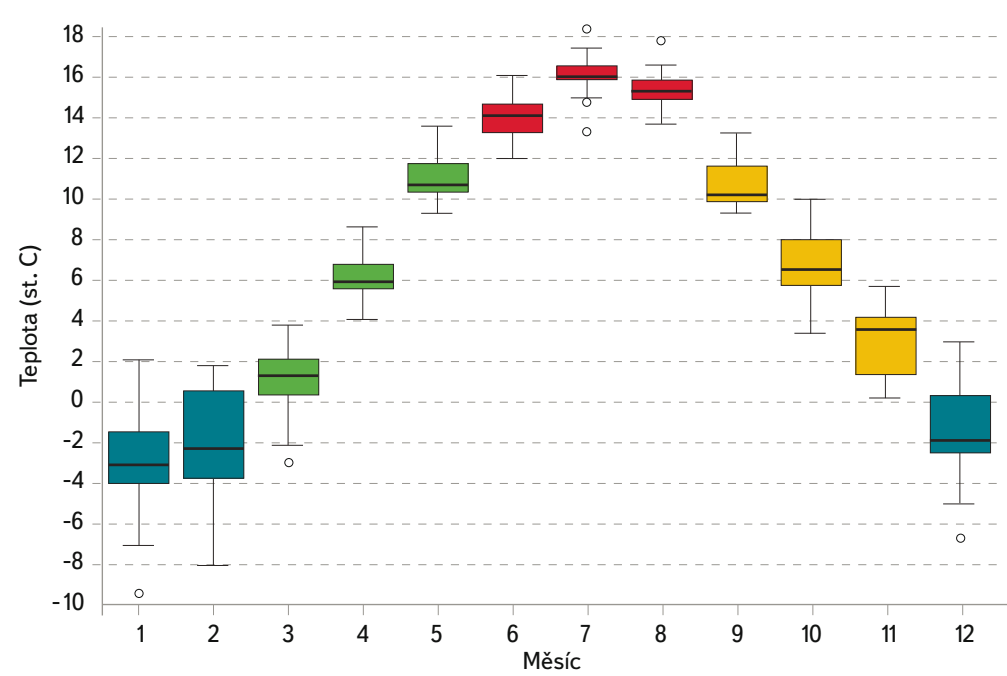

Obr. 9. Prưměrný roční chod teploty po jednotlivých měsících (barevně ohraničeny

hodnoty mezi 25 a 75\% kvantilem, dělicí čára v této oblasti představuje hodnotu mediánu, tečkovanou čarou s ohraničením jsou zobrazeny hodnoty mezi 5 a 95\% kvantilem, kolečky pak odlehlé nejmenší a největší hodnoty; obdobně jsou použity symboly i na obr. 20 až 27

Fig. 9. Annual air temperature distribution

Období NRV nejdřive začalo 5. ledna a nejpozději 14. dubna, průměr a medián připadá na polovinu února (medián 12. únor, průměr 16. únor). Období NRV nejdřive skončilo 29. ledna a nejpozději 20. června, medián připadá na 24. únor a průměr na 13. březen (pozdější hodnota průměru je dána zejména velmi pozdními konci období NRV v letech 2008 a 2013). V roce 2008 trvalo období NRV od 25. března do 31. května, tzn. 68 dnů. Období NRP začalo nejdřive 4. listopadu a nejpozději 22. ledna, střední hodnoty výskytu připadají na 22. prosinec (průměr), resp. 23. prosinec (medián). Období NRP končilo mezi 8. prosincem a 3. únorem, kde medián hodnot připadá na 31. prosinec a průměr na 3. leden. Variabilita výskytu období NRV a NRP je ukázána na obr. 10.

\section{Datum výskytu nejnižší a nejvyšší teploty během dne, období největšího růstu a poklesu teploty}

Roční chod teploty vzduchu je jednoznačný - minimum teploty bývá v zimním půlroce, maximum v letním půlroce. $V$ denním chodu zpravidla bývá (obr. 14) minimum ráno a maximum odpoledne, avšak zejména při malé denní amplitudě vzduchu či při přechodu front tomu tak být nemusí a mưže být minimum a maximum teploty kdykoliv během dne (obr. 12). Tyto prípady jsou typické hlavně pro zimu, avšak ve výjimečných prípadech tato situace může nastat i v létě. Přestože je variabilita denních chodů teploty vzduchu značná, tak v měsíčním průměru ve všech prípadech převládá již obvyklý denní chod teploty (obr. 13) s ranním minimem mezi 4. a 8. hodinou ranní (minimum se vyskytuje před východem Slunce) a odpoledním maximem (mezi 12. a 16. hodinou). V zimě nastává při typickém denním chodu maximum dřive (většinou do 1 hodiny po kulminaci Slunce), v létě později (až 3 hodiny po kulminaci Slunce; $\checkmark$ létě je Slunce výše, více prohřeje vzduch). $v$ jednotlivých letech se průměrné měsíční chody teploty vzduchu mírně liší. Zprůměruje-li se denní chod teploty ze všech dnů v roce, pak je zcela vyhlazený a meziročně se nemění (shodný tvar jako na obr. 15), nejnižší teplota nastává po 4. hodině ranní a nejvyšší před 14. hodinou. Meziročně se liší pouze suma odchylek teploty od průměru.

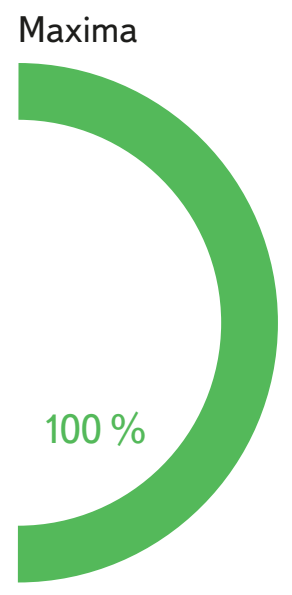

UU

\section{Minima}

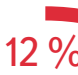

VU

UV

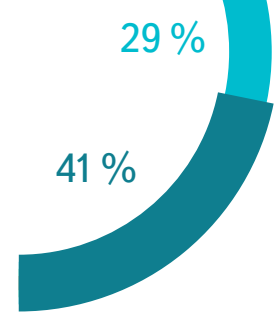

VV

Obr. 11. Zastoupení jednotlivých typů extrémů v ročním chodu

Fig. 11. Representation of individual types of extremes

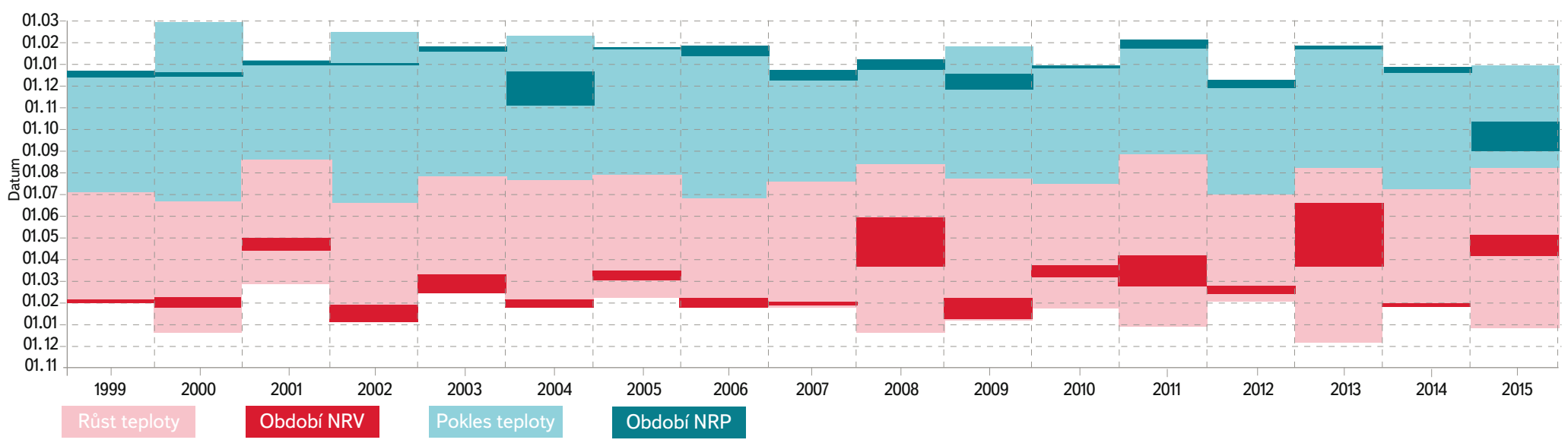

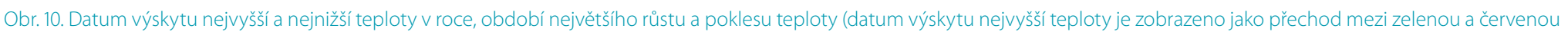
barvou, datum výskytu nejnižší teploty jako přechod mezi bílou a červenou barvou)

Fig. 10. Dates of the highest and lowest temperatures of the year, the period of the biggest growth and decrease in temperature 


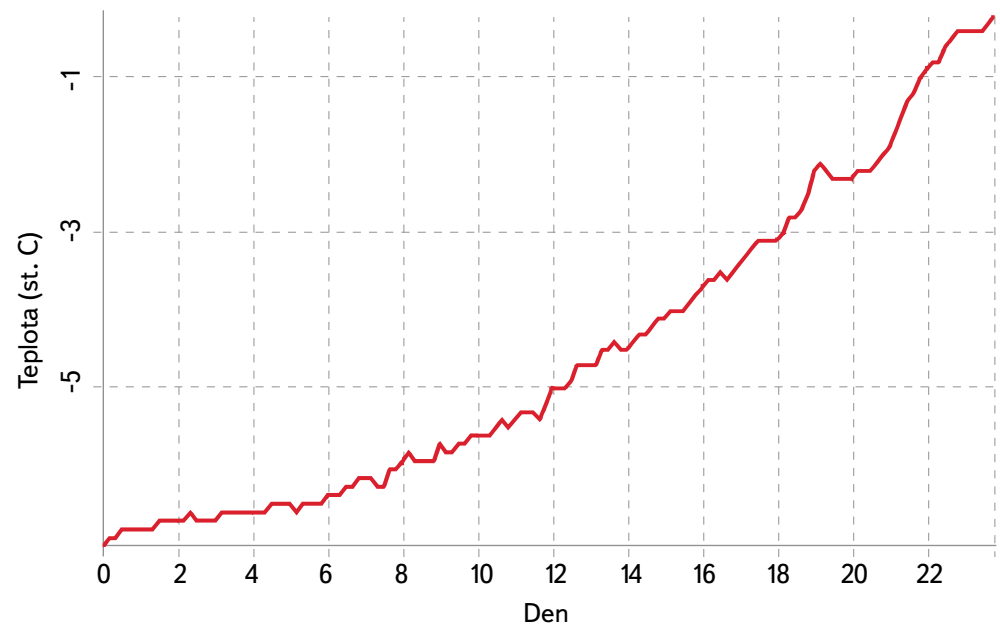

a) Denní chod z 6.1. 2011 v časovém intervalu 10 minut

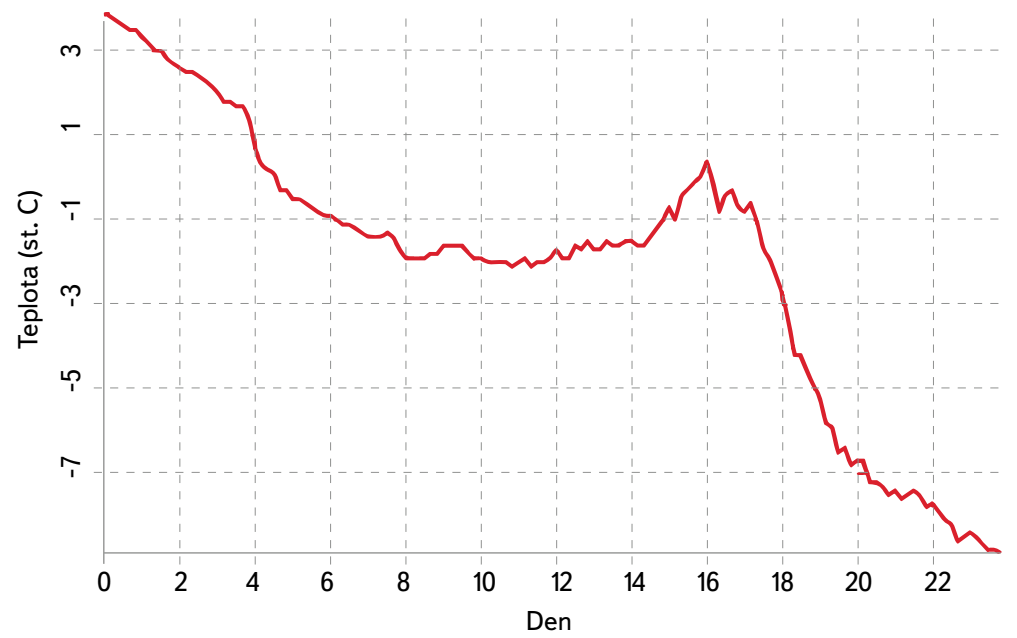

b) Denní chod z 22. 3. 2015 v časovém intervalu 10 minut

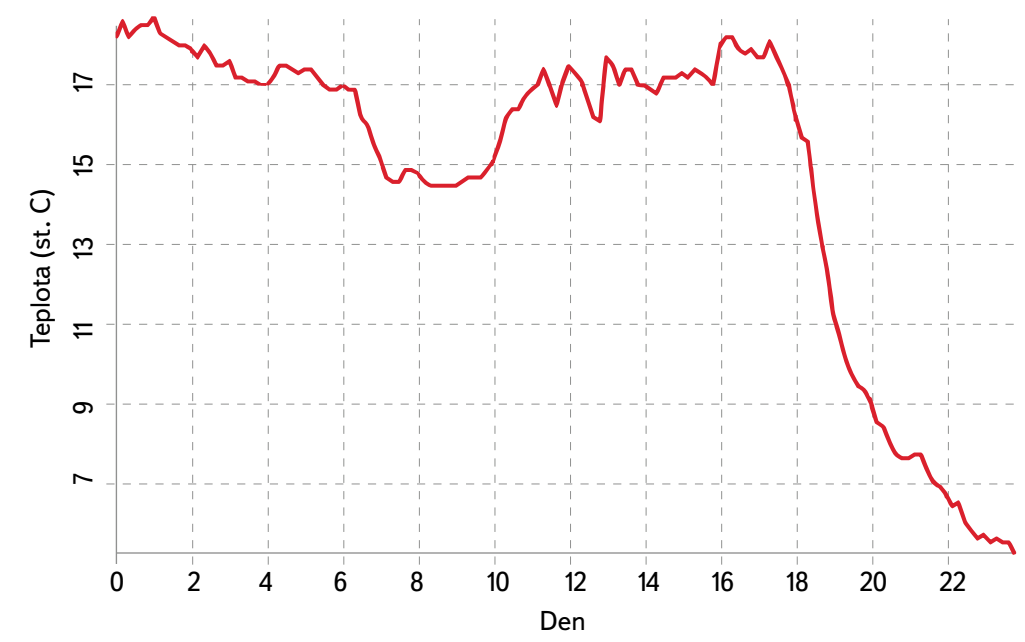

c) Denní chod z 25. 8. 2015 v časovém intervalu 10 minut

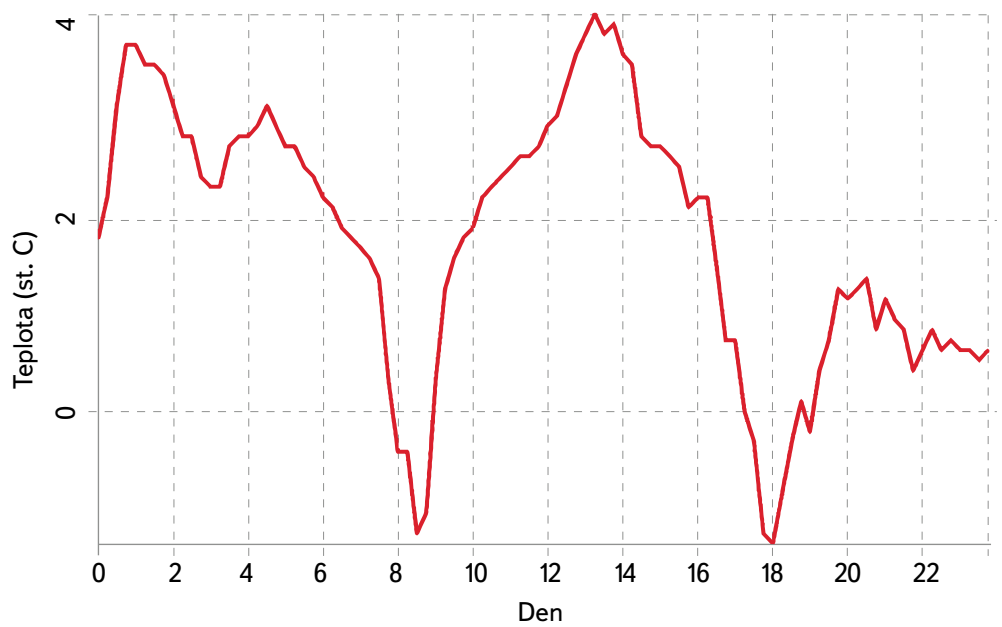

d) Denní chod z 25. 1. 2008 v časovém intervalu 15 minut

Obr. 12. Príklady atypického denního chodu teploty vzduchu

Fig. 12. An example of an atypical distribution of air temperature

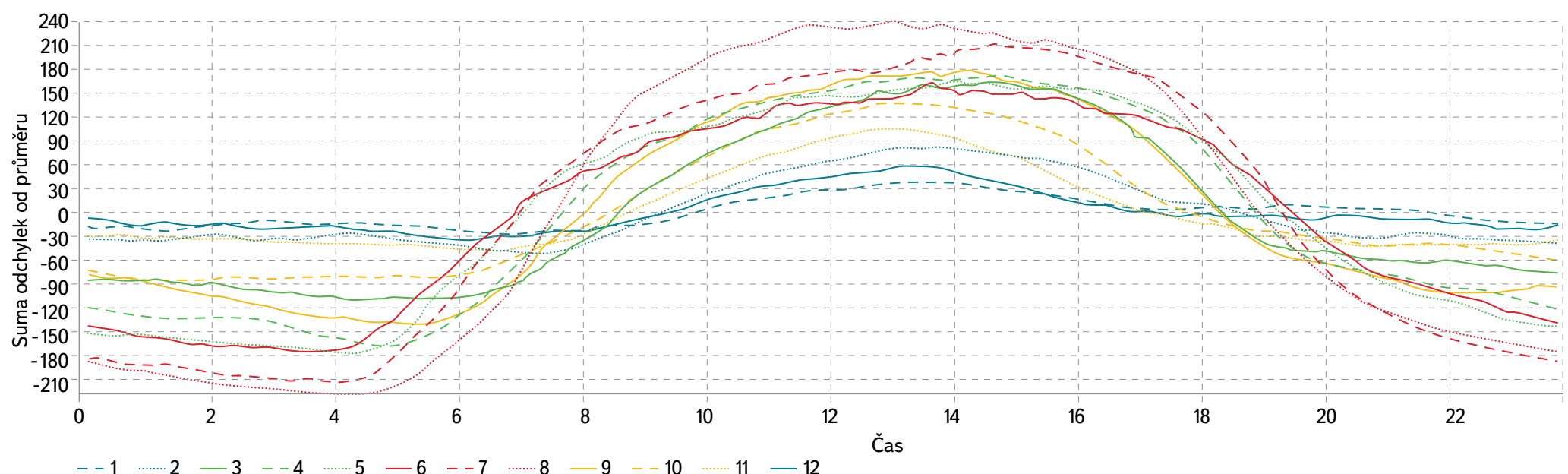

Obr. 13. Průměrný denní chod teploty vzduchu v jednotlivých měsících roku 2015 v časovém intervalu 10 minut

Fig. 13. Average daily distribution of air temperature 


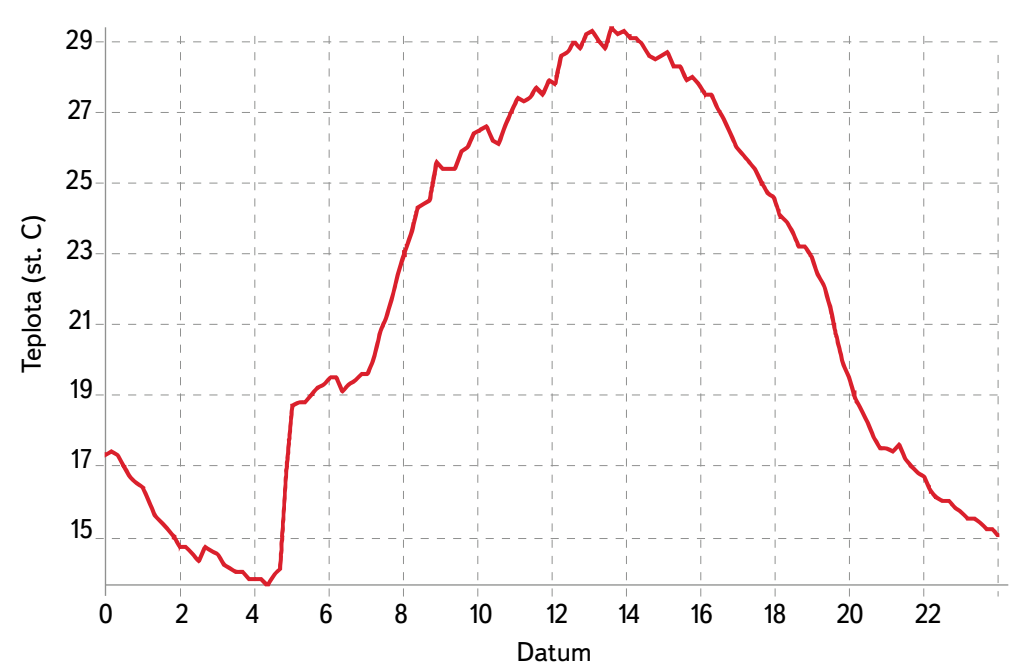

Obr. 14. Príklad typického denního chodu teploty vzduchu - denní chod teploty vzduchu z 9. 8. 2015 v časovém intervalu 10 minut

Fig. 14. An example of a typical distribution of air temperature

K analýze denního chodu teploty vzduchu je možno stejně jako k analýze ročního chodu teploty vzduchu použít metodu součtových řad, přičemž minimum a maximum teploty se nebude hledat $v$ řadě denních teplot, ale $v$ řadě 10 (resp. 15) minutových teplot. Období NRV se hledá mezi 10. a 20. hodinou a období NRP mezi 20. a 10. hodinou.

Metoda součtových řad početně jiným způsobem dokazuje hlavní vliv výšky Slunce na denní chod teploty vzduchu (obr. 17). Dalšími faktory je charakter počasí (přechod front, bouřková činnost ap.) a oblačnost (zejména v zimním období při malé teplotní amplitudě).

Vlivem těchto faktorů jednoznačně dominuje typ extrému UU (86\% u minima teploty, 83 \% u maxima teploty), přičemž typ VV se vyskytuje pouze ve $2 \%$ př́padů (obr. 16). Průměrná poloha období NRV a NRP přesně odpovídá nejstrmější části křivky průměrného denního chodu teploty.

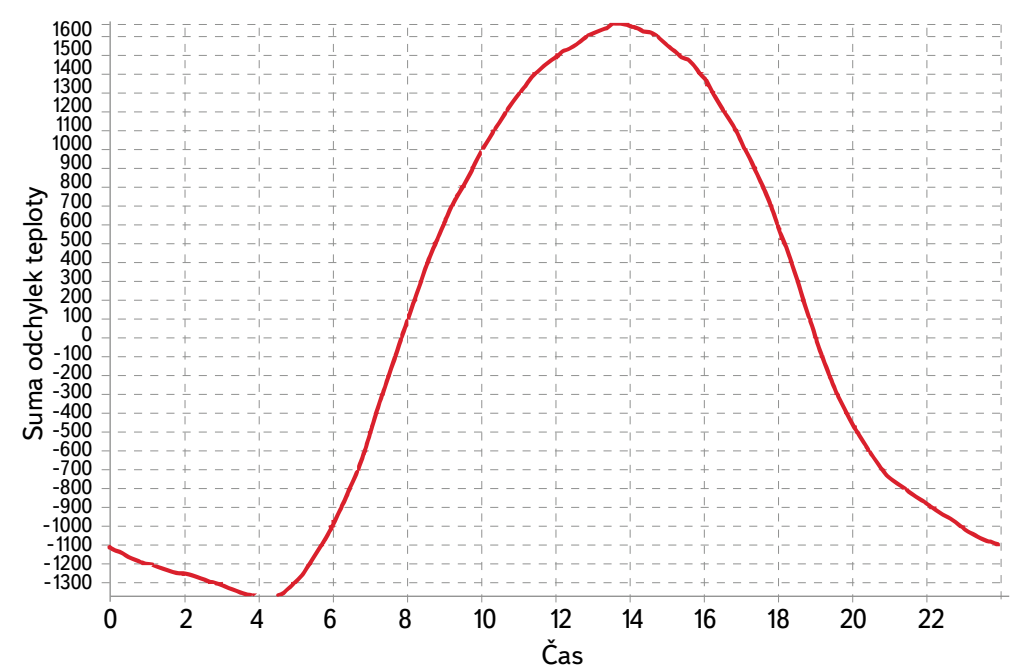

Obr. 15. Průměrný denní chod teploty vzduchu v roce 2015 v časovém intervalu 10 minut Fig. 15. Average daily distribution of air temperature

\section{Maxima}

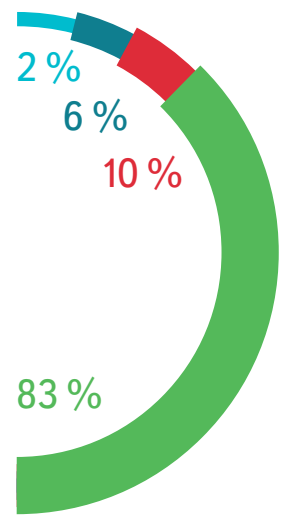

UU

VU

UV

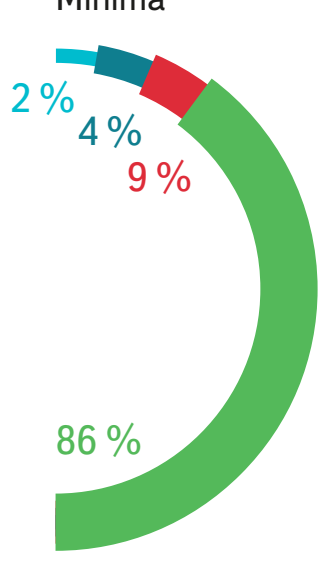

VV
Obr. 16. Zastoupení jednotlivých typů extrémů v denním chodu

Fig. 16. Representation of individual types of extremes

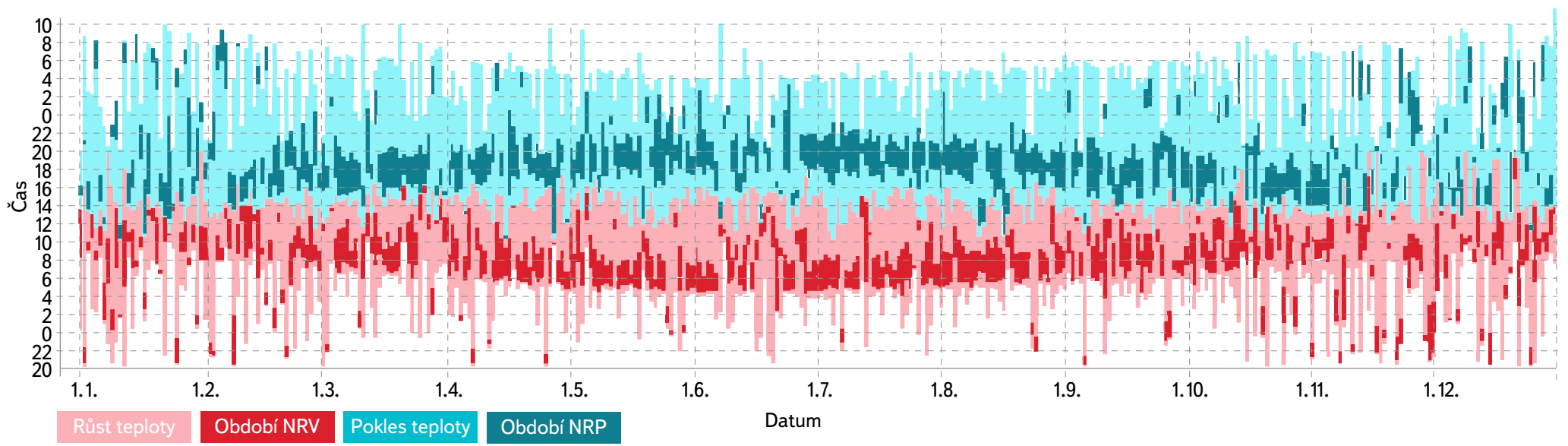

Obr. 17. Čas výskytu nejvyšší a nejnižší teploty během dne, období největšího růstu a poklesu teploty během jednotlivých dnů roku 2015

Fig. 17. Time of occurrence of the highest and lowest temperatures during the day, greatest period of growth and a drop in temperature across days of 2015 


\section{SRÁŽKY}

Průměrný roční úhrn srážek je 730 mm, nejvyšší úhrn srážek byl naměřen v roce 2010 - téměř 913 mm, nejnižší 565 mm - v roce 2015 (tabulka 5, obr. 18, obr. 30). Průměrný počet dnů beze srážek (dnem beze srážek se rozumí den s nulovými nebo neměřitelnými srážkami do $0,1 \mathrm{~mm}$; den se srážkou se rozumí den s úhrnem srážek větším nebo rovným 0,1mm) je 162 dnů, což je príibližně 44 \% všech dnů. Největší sucho, definované na základě počtu bezesrážkových dnů, bylo v roce 2011, beze srážek bylo 205 dnů, nejmenší pak v roce 2001, beze srážek bylo 134 dnů. Dochází k pozvolnému růstu počtu dnů beze srážek (obr. 19). Naopak počet dnů s úhrnem srážek nad $10 \mathrm{~mm}$ (tzn. včetně $10,0 \mathrm{~mm}$ ) dlouhodobě nevykazuje změnu $v$ trendu. $V$ průměru se vyskytuje 18,5 dne se srážkami vyššími než 10 mm, což je obdobná hodnota jako medián (18 mm). Nejvíce dnů se srážkami nad $10 \mathrm{~mm}$ bylo v roce 2010 - 22 dnů, nejméně v roce 2015 - 12 dnů. Na Bučnici se nevyskytl žádný kalendářní měsíc zcela beze srážek, nule se blížil úhrn srážek v listopadu 2011 - úhrn 0,1mm (beze srážek bylo období od 28. ŕijna do 29. listopadu, 30. listopadu v 16:00 bylo změřeno 0,1 mm, souvislé období se srážkami pak začalo 3. prosince). Úhrn do $10 \mathrm{~mm}$ (obr. 31) byl zaznamenán v 7 měsících, úhrn do $20 \mathrm{~mm}$ v 16 měsících. Nejvyšší měsiční úhrn srážek byl změřen v srpnu 2006 - 209,9mm, což je jediný měsíc s úhrnem srážek nad 200 mm. Úhrn nad 100 mm byl zaznamenán ve 27 měsících. Při uvažování ročního chodu byl nejextrémnější únor 2002, kdy bylo naměřeno o více než 200 \% srážek, než je v únoru obvyklé. Nejvyšší denní srážky byly 7. srpna 2006 - 61 mm.

Pro analýzu sucha je důležité porovnání úhrnu srážek $s$ velikostí teploty vzduchu. Z tohoto hlediska byly roky s nejnepříznivější kombinací malého úhrnu srážek a nadprůměrné teploty vzduchu roky 2014 a 2015, v měsíčním hodnocení jsou období s nejmenšími srážkami a větší odchylkou teploty vzduchu (obr. 31) hlavně v zimních měsících. Z měsíců mimo zimní období byl úhrn srážek do $20 \mathrm{~mm}$ a odchylka teploty nad $3^{\circ} \mathrm{C}$ pouze $v$ jednom měsíci - říjnu 2000 (průměrná teplota $9,8^{\circ} \mathrm{C}$, což je o $3^{\circ} \mathrm{C}$ více než je prưměr, srážky $18 \mathrm{~mm}$, což je o 60 \% méně než je průměr).

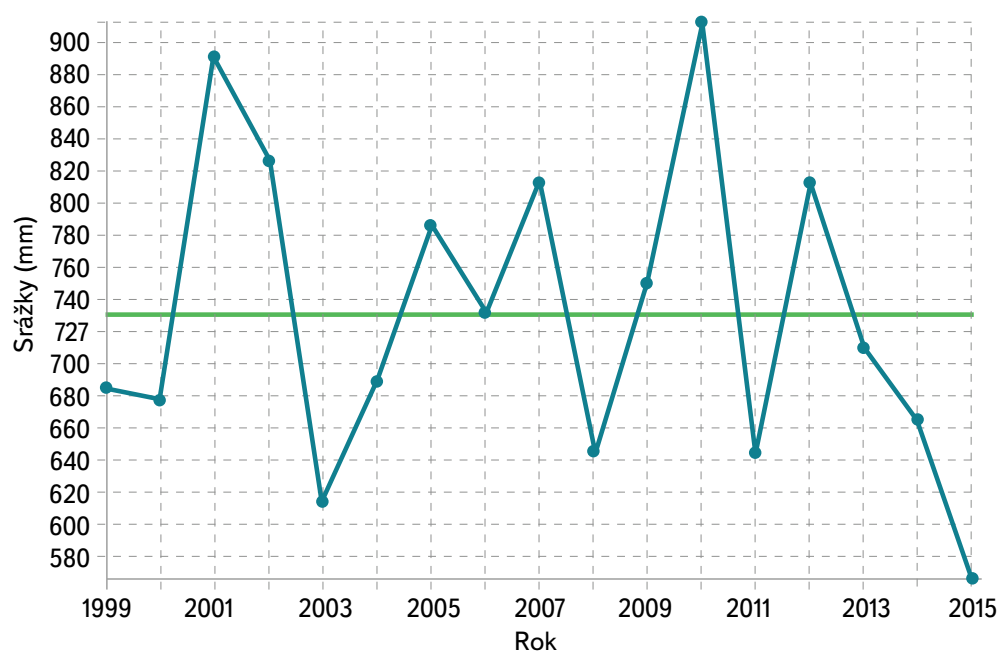

Obr. 18. Úhrn srážek v jednotlivých letech (zeleně vyznačen průměr za celé období) Fig. 18. Total precipitation

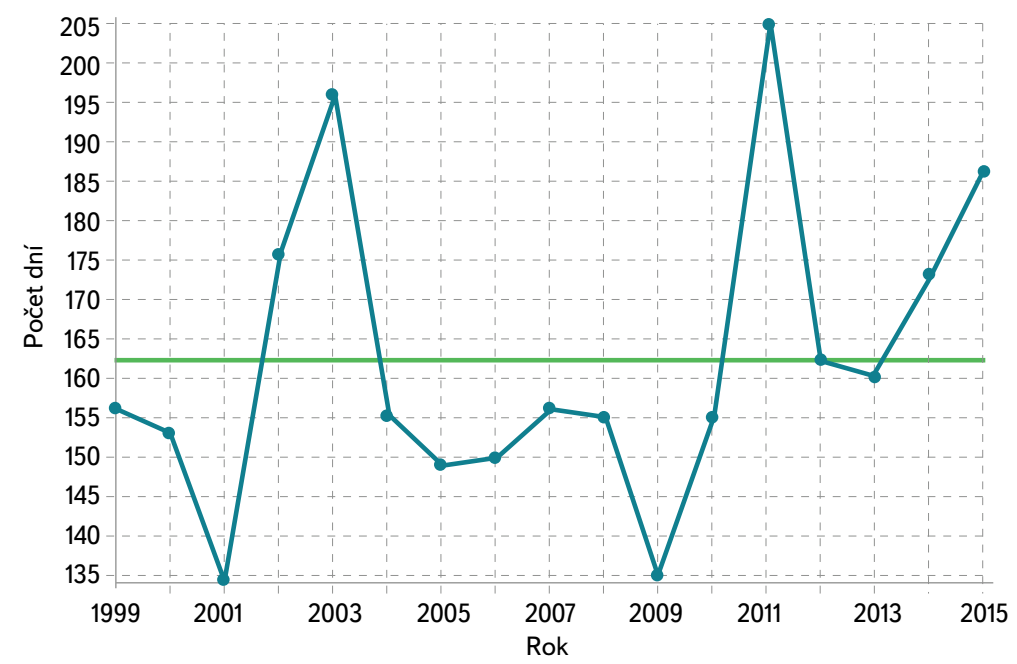

Obr. 19. Počet dnů beze srážek v jednotlivých letech (zeleně vyznačen prưměr za celé obdobî) Fig. 19. Number of days without precipitation

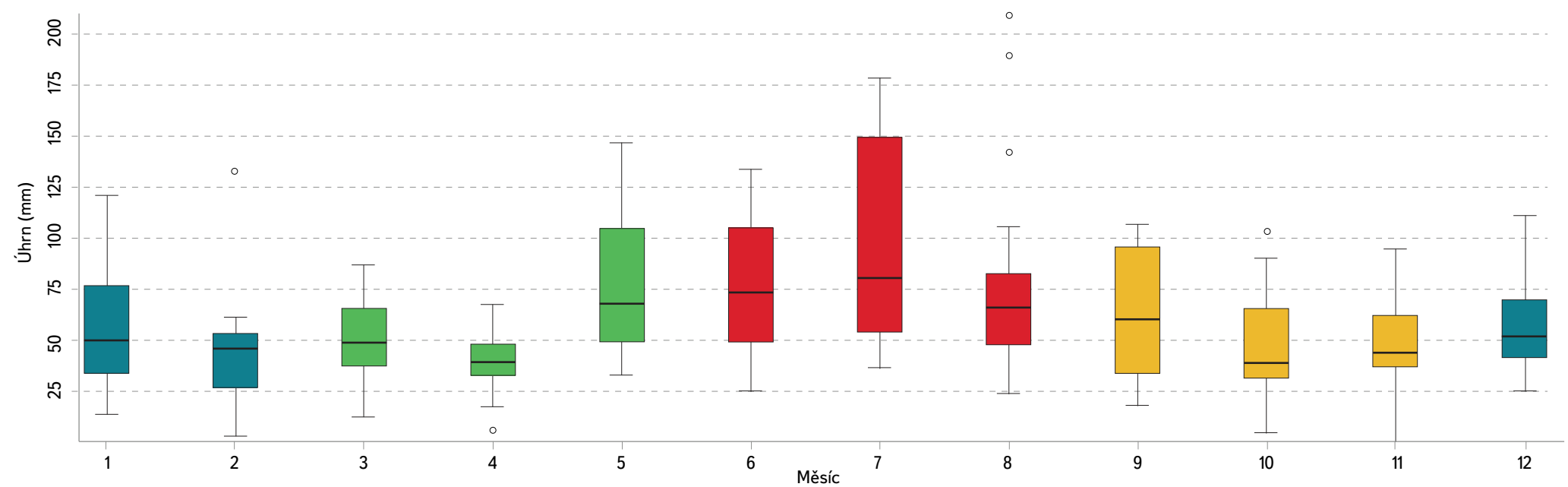

Obr. 20. Roční chod srážek v jednotlivých měsících (zobrazen měsíční 5, 25, 50, 75, 95\% kvantil, kolečky odlehlé hodnoty)

Fig. 20. Annual precipitation distribution 
Vzhledem k velké proměnlivosti srážek během jednotlivých dnů má smys| posuzovat roční chod srážek pouze na základě měsíčních srážkových úhrnů. Nejvíce srážek spadne $v$ průměru $\vee$ červenci $(96 \mathrm{~mm})$, nejméně $\vee$ dubnu (38,5 mm), v únoru $(43,1 \mathrm{~mm})$ a řijnu $(45 \mathrm{~mm})$. V ročním chodu je výrazné maximum srážek $v$ létě (květen až srpen $s$ maximem $v$ červenci) a podružné maximum v zimě (prosinec, leden), minima srážek pak na přelomu zimy a jara a na podzim. Letní hlavní maximum srážek a zimní podružné maximum souvisí se zesílenými návětrnými efekty JZ kvadrantu. Úhrny srážek v měsíci červenci jsou značně variabilní - směrodatná odchylka je 46,7 mm, rozpětí mezi 25\% kvantilem $(53,7 \mathrm{~mm})$ a $75 \%$ kvantilem (149,6 mm) téměř 100 mm srážek. Měsíc červenec je i měsíc s nejvyššími denními srážkami - průměrně se vyskytuje alespoň 1 den se srážkou 26,1mm, nejmenší maximální denní úhrny bývají v únoru (průměr 10,5 mm, maximum 26,6 mm). Ve většině měsíců tvoří maximální denní úhrn srážek necelou třetinu měsíčního úhrnu srážek - největší je tento poměr $\checkmark$ průměru $v$ červenci $(34,5 \%)$, nejmenší v lednu (24,3\%), přičemž v lednu je i v nejnepříznivějším prípadě tento poměr zhruba třetinový (33,7 \%). Měsíc s největším počtem dní se srážkou je měsíc srpen (průměr 20 dnů, medián 18 dnů) a červenec (průměr 19,6 dnů, medián 21 dnů), měsíc s nejmenším počtem dnů se srážkou duben (průměr i medián 13 dnů), přičemž $\vee$ měsíci srpnu byl nejmenší počet dnů se srážkou 15 dnů. V srpnu se vyskytuje i nejvíc dnů s vysokým

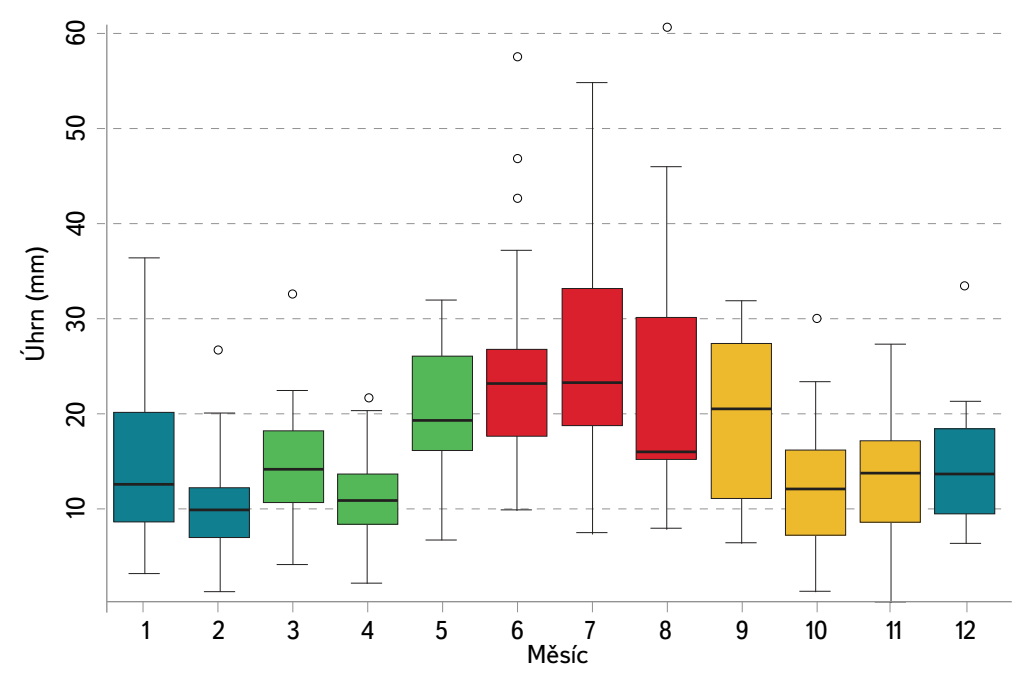

Obr. 21. Maximální denní úhrny srážek v jednotlivých měsících (zobrazen měsiční 5, 25, 50, 75, 95\% kvantil, kolečky odlehlé hodnoty)

Fig. 21. Maximum precipitation

Tabulka 5. Vybrané srážkové charakteristiky

Table 5. Precipitation characteristics

\begin{tabular}{|c|c|c|c|c|c|c|c|}
\hline Rok & $\begin{array}{l}\text { Roční úhrn } \\
\text { (mm) }\end{array}$ & $\begin{array}{l}\text { Měsíční } \\
\text { maximum } \\
(\mathrm{mm})\end{array}$ & $\begin{array}{c}\text { Měsíční } \\
\text { minimum (mm) }\end{array}$ & $\begin{array}{c}\text { Denní } \\
\text { maximum } \\
(\mathrm{mm})\end{array}$ & $\begin{array}{l}\text { Počet dní } \\
\text { beze srážek }\end{array}$ & $\begin{array}{l}\text { Počet dní } \\
\text { se srážkami } \\
\text { do } 1 \mathrm{~mm}\end{array}$ & $\begin{array}{l}\text { Počet dní } \\
\text { se srážkami } \\
\text { nad } 10 \text { mm }\end{array}$ \\
\hline 1999 & 683,3 & 133,7 & 33,9 & 37,2 & 156 & 233 & 14 \\
\hline 2000 & 677,0 & 93,8 & 17,3 & 24,8 & 153 & 239 & 14 \\
\hline 2001 & 891,0 & 178,6 & 32,1 & 41,4 & 134 & 220 & 24 \\
\hline 2002 & 826,3 & 132,6 & 32,9 & 46,7 & 176 & 239 & 22 \\
\hline 2003 & 613,5 & 111,7 & 12,2 & 32,0 & 196 & 270 & 13 \\
\hline 2004 & 688,7 & 118,6 & 33,5 & 57,8 & 155 & 238 & 13 \\
\hline 2005 & 786,0 & 157,0 & 4,7 & 27,4 & 149 & 238 & 20 \\
\hline 2006 & 731,6 & 209,9 & 13,8 & 60,8 & 150 & 235 & 17 \\
\hline 2007 & 812,6 & 154,5 & 5,9 & 33,5 & 156 & 227 & 25 \\
\hline 2008 & 644,8 & 78,7 & 25,5 & 32,5 & 155 & 253 & 20 \\
\hline 2009 & 750,6 & 110,8 & 5,6 & 26,1 & 135 & 229 & 18 \\
\hline 2010 & 912,7 & 189,2 & 9,3 & 46,0 & 155 & 232 & 26 \\
\hline 2011 & 643,9 & 161,5 & 0,1 & 42,2 & 205 & 275 & 19 \\
\hline 2012 & 811,9 & 149,6 & 17,1 & 54,9 & 162 & 253 & 25 \\
\hline 2013 & 709,5 & 113,2 & 31,1 & 45,8 & 160 & 249 & 17 \\
\hline 2014 & 664,7 & 138,0 & 3,1 & 23,8 & 173 & 251 & 16 \\
\hline 2015 & 565,0 & 79,6 & 10,1 & 23,4 & 186 & 260 & 12 \\
\hline Průměr & 730,2 & 135,9 & 17,0 & 38,6 & 162 & 244 & 19 \\
\hline Minimum & 565,0 & 78,7 & 0,1 & 23,4 & 134 & 220 & 12 \\
\hline Maximum & 912,7 & 209,9 & 33,9 & 60,8 & 205 & 275 & 26 \\
\hline Medián & 709,5 & 133,7 & 13,8 & 37,2 & 156 & 239 & 18 \\
\hline
\end{tabular}




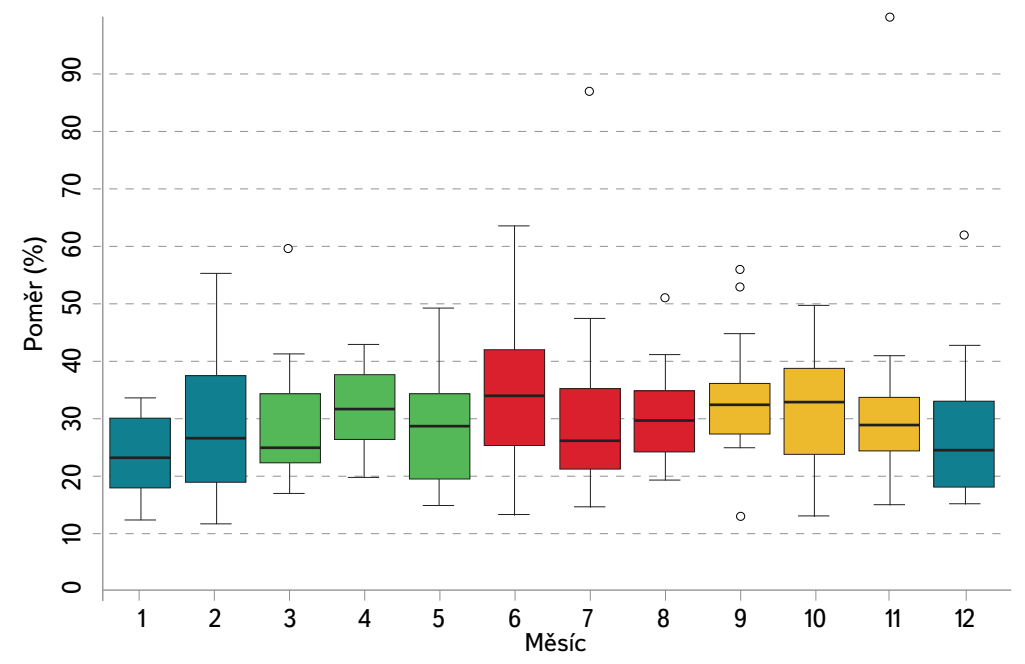

Obr. 22. Poměr mezi měsíčním úhrnem srážek a maximálním denním úhrnem (zobrazen měsíční 5, 25, 50, 75, 95\% kvantil, kolečky odlehlé hodnoty)

Fig. 22. The ratio between monthly rainfall and maximum daily total

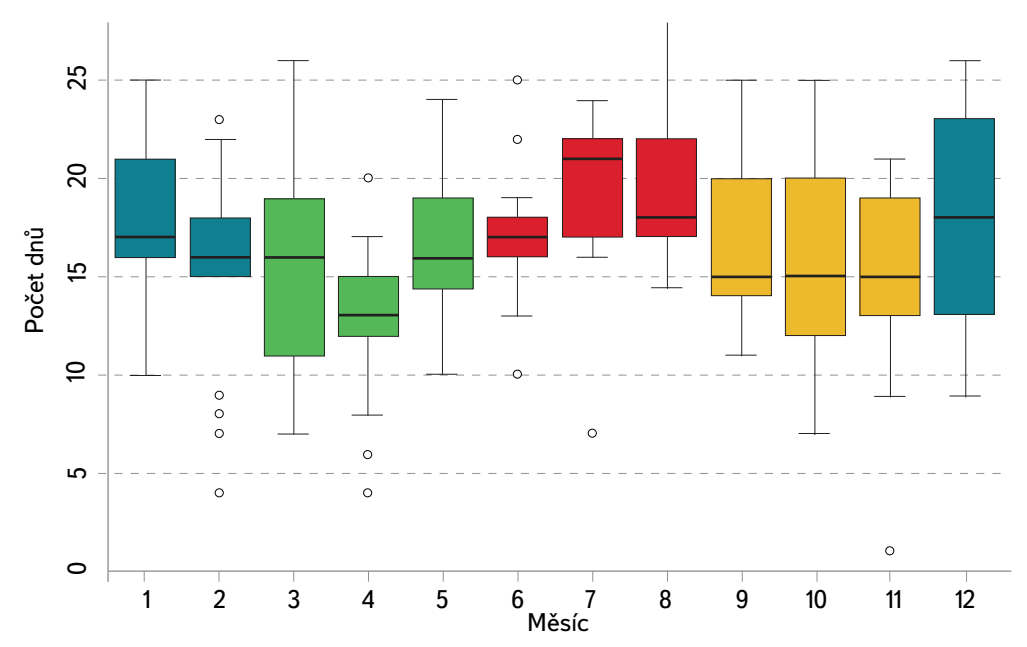

Obr. 23. Počet dnů se srážkou (zobrazen měsíční 5, 25, 50, 75, 95\% kvantil, kolečky odlehlé hodnoty)

Fig. 23. Number of days with precipitation

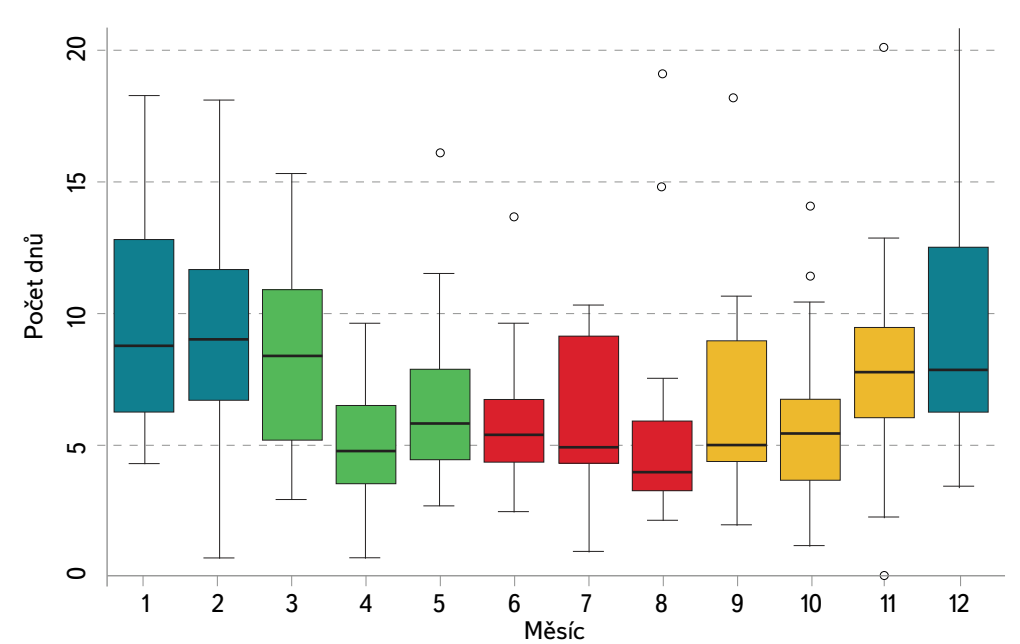

Obr. 24. Počet dnů beze srážek (zobrazen měsíční 5, 25, 50, 75, 95\% kvantil, kolečky odlehlé hodnoty)

Fig. 24. Number of days without precipitation

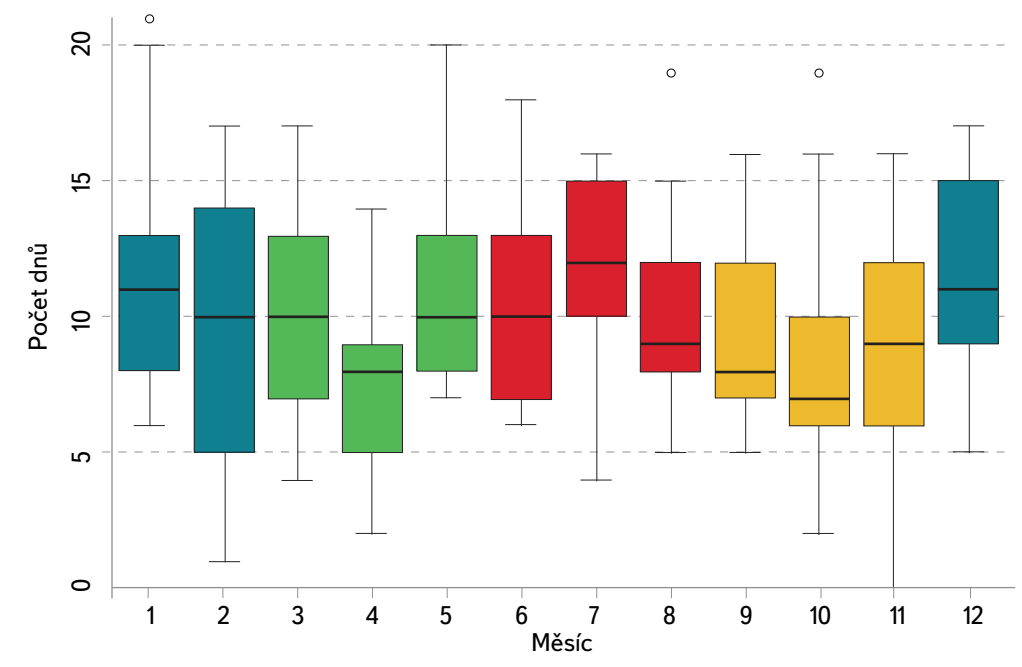

Obr. 25. Počet dnů se srážkou vyšší než 1 mm (zobrazen měsíční 5, 25, 50, 75, 95\% kvantil, kolečky odlehlé hodnoty)

Fig. 25. Number of days with precipitation over $1 \mathrm{~mm}$

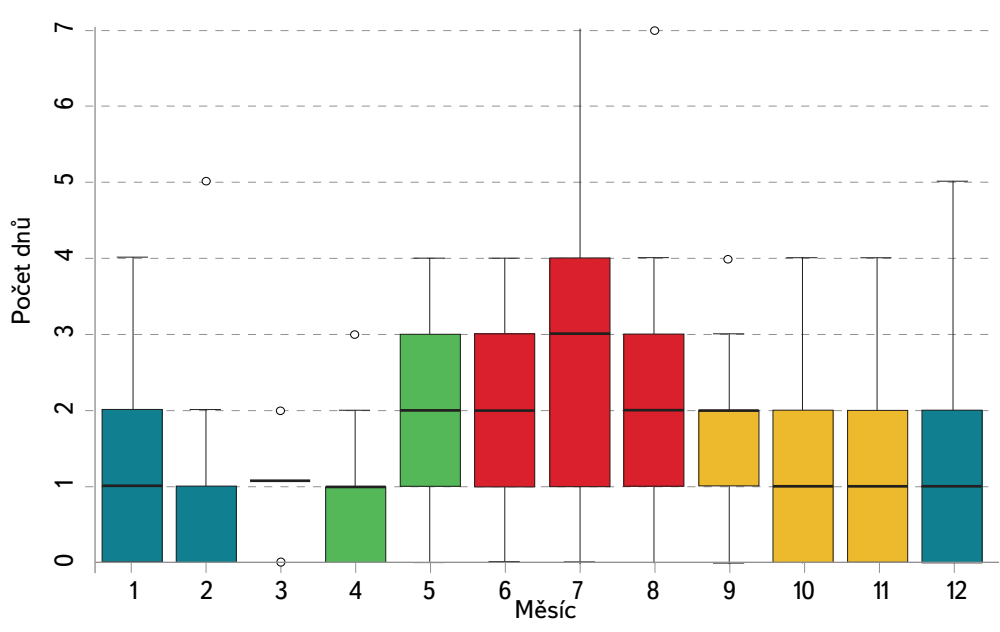

Obr. 26. Počet dnů se srážkou vyšší než 10 mm (zobrazen měsiční 5, 25, 50, 75, 95\% kvantil, kolečky odlehlé hodnoty)

Fig. 26. Number of days with precipitation over $10 \mathrm{~mm}$

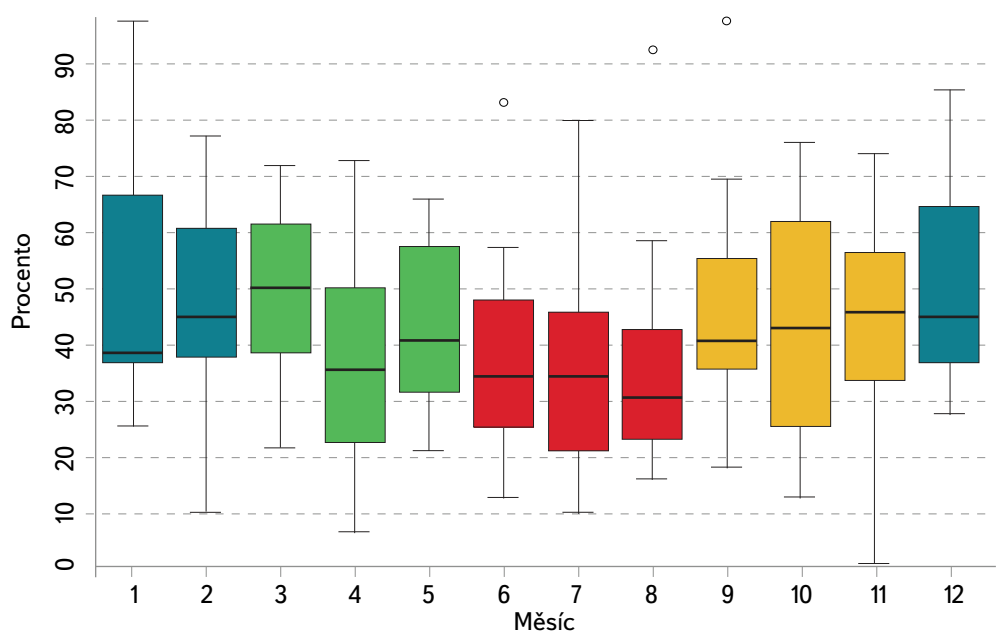

Obr. 27. Procento srážek během dne s nejdelším trváním srážek v měsíci (zobrazen měsíční 5, 25, 50, 75, 95\% kvantil, kolečky odlehlé hodnoty)

Fig. 27. Percentage of rainfall during the day with the longest duration of rainfall in a month 
úhrnem srážek nad 10 mm - v průměru tři dny. Roční rozpětí mezi průměrným počtem minima a maxima počtu dnů se srážkami nad $1 \mathrm{~mm}$ je velmi malé necelé čtyři dny. Nejmenší počet těchto dnů je v dubnu (7,6 dnů), největší v červenci (11,7 dnů). Z hlediska nejdelšího trvání srážky během jednoho dne u dne s nejdelším trváním srážky během jednoho dne během jednoho měsíce je toto období nejdelší v zimě - prosinec a leden v průměru kolem 50,3 \% dne a nejméně v červenci 34,8 \% dne. Podrobnější statistické vyhodnocení vybraných srážkových ukazatelů Ize nalézt na obr. 20 až 27.

Průměrný roční chod srážek je v souladu s literaturou. O jeho variabilitě v jednotlivých krajích podrobněji v [5]. V celkových úhrnech srážek jsou zahrnuty jak dny, v nichž dominují padající srážky, tak dny, v nichž převažují srážky vzniklé kondenzací vody. Díky nim může být denní úhrn srážek i 0,5 mm. Z tohoto důvodu se na Bučnici nevyskytl žádný měsíc, který by byl zcela beze srážek.

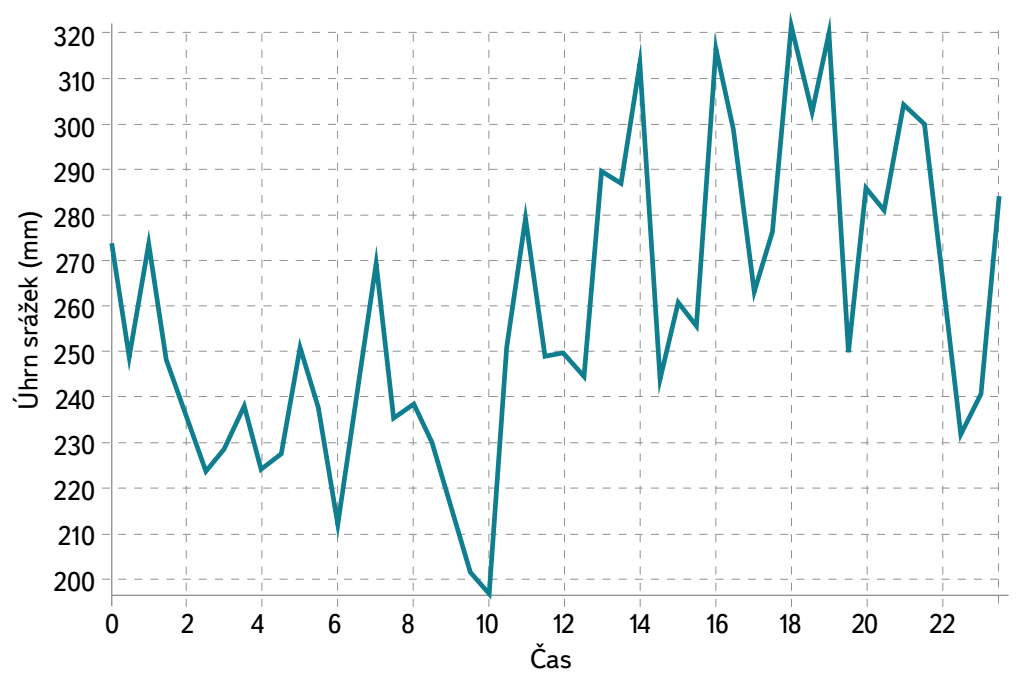

Obr. 28. Denní chod srážek (sestrojený na základě sumy srážek pro 30minutové intervaly všech dnů celého období)

Fig. 28. Daily precipitation distribution

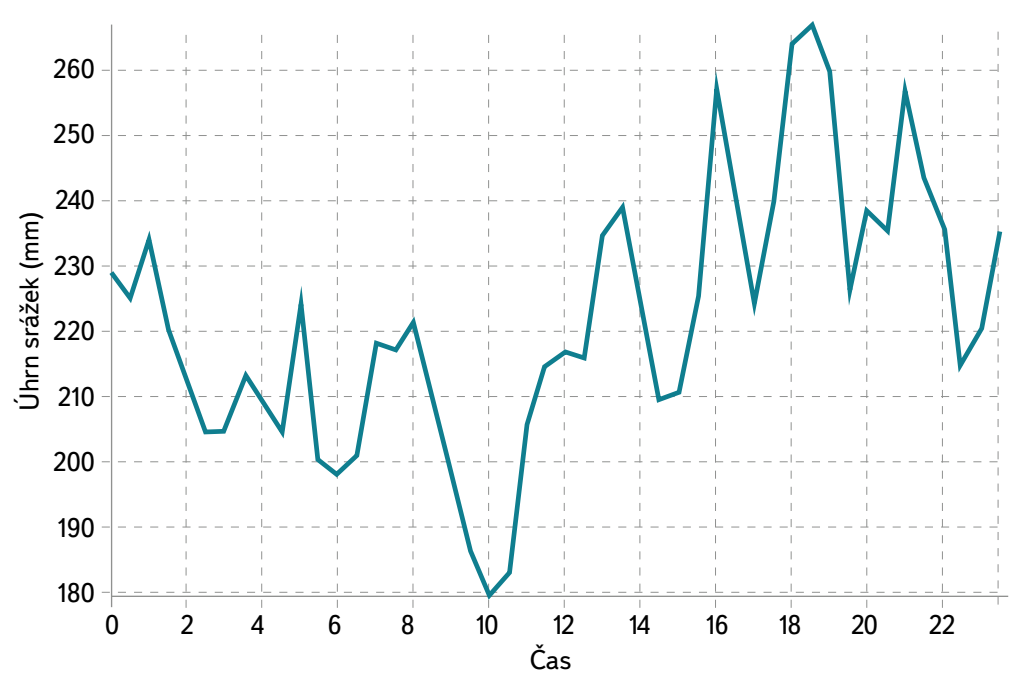

Obr. 29. Denní chod srážek (sestrojený na základě sumy srážek pro 30 minutové intervaly všech dnů celého období, přičemž v každém 30minutovém období bylo vynecháno pět největších srážkových epizod)

Fig. 29. Daily precipitation distribution - without 5 biggest rainfall episodes in every period
Obdobným způsobem jako u teploty vzduchu Ize přistoupit k analýze denního chodu srážek. Ten je vzhledem k ještě větší proměnlivosti hodnot nepravidelnější, nicméně z ročních úhrnů je denní chod již patrný (obr. 28). Vzhledem k možnému ovlivnění chodu srážkami z prívalových deštư je vhodné denní chod o tyto epizody očistit (obr. 29). Na očištěných datech je jasné dopolední srážkové minimum (kolem 10. hodiny) a podvečerní maximum (kolem 18. hodiny).

\section{ZÁVĚR}

Průměrná roční teplota vzduchu je na Bučnici $6,46^{\circ} \mathrm{C}$. Za 17leté období 1999-2015 se otepluje v průměru o $0,04^{\circ} \mathrm{C} /$ rok. Celkové oteplování se projevuje zvyšováním počtu dnů v jednotlivých intervalech s teplotou nad $10^{\circ} \mathrm{C}$. Nejteplejším měsícem je měsíc červenec s průměrnou teplotou $16,1^{\circ} \mathrm{C}$, nejchladnějším měsícem leden s teplotou $-3,1^{\circ} \mathrm{C}$. Nejčastějším měsícem výskytu ročního maxima teploty je měsíc červenec (53\% prípadů), následuje měsíc srpen (29\%) a červen (18\%), nejchladnějším měsícem je leden (47 \% prípadů), následuje prosinec (29 \%) a únor (24 \%). Nejnižší teplota v roce se nejčastěji vyskytuje 24. ledna, přičemž je patrný významný propad teploty vzduchu v období mezi 19. lednem a 5. únorem. Nejteplejším obdobím roku je období mezi 16. červencem a 8. srpnem, v tomto období nejsou př́liš výrazné výkyvy teploty. Prưměr z výskytu maxim teploty studovaného 17letého období připadá na 20. červenec, medián na 21. červenec. Podle křivky sestrojené na základě kumulace součtu odchylek teploty vzduchu jednotlivých dnů od ročního průměru př́slušného roku za celé období pozorování připadá maximum teploty na 29. červenec. Nejvýraznějšími teplotními singularitami je květnové ochlazení (v období mezi 10. až 14. květnem), červnové ochlazení po 10. červnu, babí léto (mezi 19. zárím a 7. říjnem) a oteplení od druhé poloviny října do začátku listopadu. Ostatní odchylky v teplotě vzduchu jsou méně výrazné. Nejvýraznější poklesy teploty vzduchu během roku nastávají v období vpádu chladného vzduchu kolem doby výskytu ročního minima. Denní chod teploty vzduchu ovlivňuje především poloha výšky Slunce nad obzorem, pokrytí oblohy oblačností a charakter počasí.

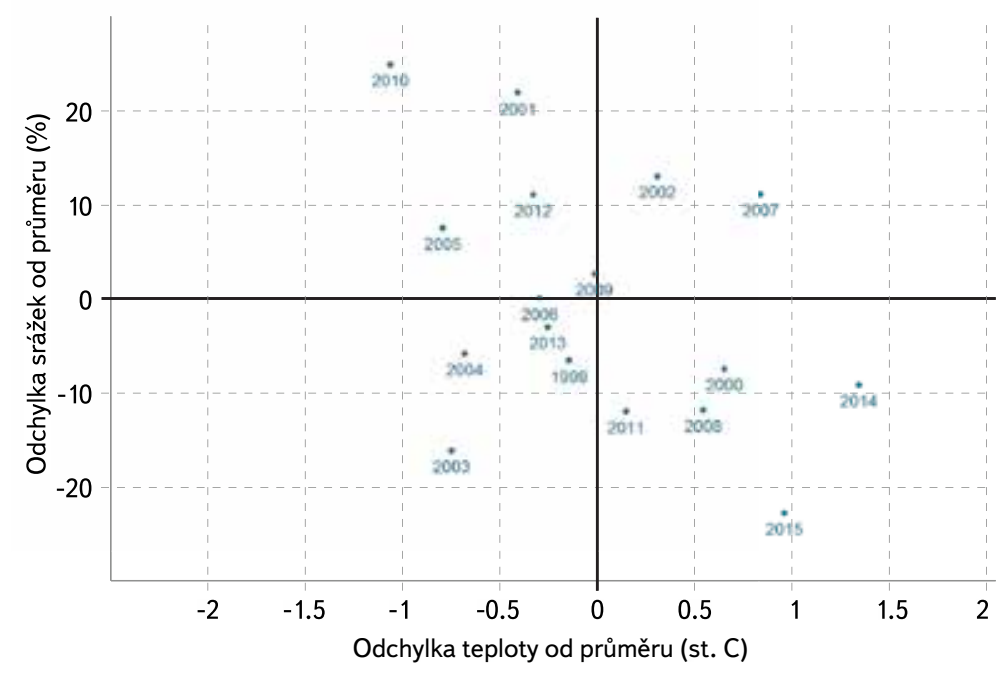

Obr. 30. Odchylka ročních teplot a srážek od průměru

Fig. 30. Deviation from annual mean air temperatures and annual precipitation 


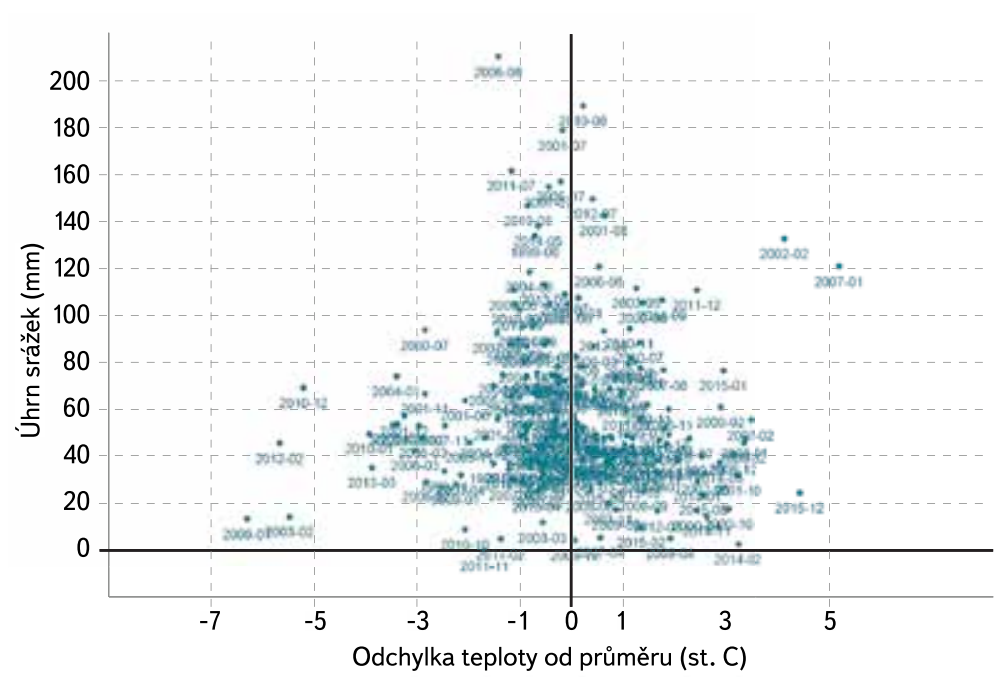

a) Srovnání odchylek teplot oproti úhrnu srážek jednotlivých měsíců

Obr. 31. Srovnání měsíčních odchylek teplot a srážek

Fig. 31. Comparison of deviations in monthly temperature and precipitation

Průměrný roční úhrn srážek je 730 mm, nejvyšší roční úhrn srážek byl 913 mm (rok 2010), nejnižší 565 mm (rok 2015). Na Bučnici se nevyskytl žádný kalendáňní měsíc zcela beze srážek, nule se bližil úhrn srážek pouze v listopadu 2011 (0,1mm). Nejvyšší měsiční úhrn srážek byl naměěen v srpnu 2006 - 209,9mm, což je jediný měsíc s úhrnem srážek nad 200 mm. Nejvyšší denní úhrn srážek byl 61 mm (7. srpna 2006). Průměrný počet dnů beze srážek je 162 dnů, což je přibližně $44 \%$ všech dnů. V ročním chodu je výrazné maximum srážek v létě (květen až srpen $\mathrm{s}$ maximem $\vee$ červenci $-96 \mathrm{~mm}$ ) a podružné maximum $\vee$ zimě (prosinec, leden), což souvisí s návětrným efektem terénu. Minima srážek připadají na přelom zimy a jara (duben - 38,5 mm, únor - 43,1 mm) a na podzim (ř́ijen - $45 \mathrm{~mm}$ ). Ve většině měsíců tvorí maximální denní úhrn srážek necelou třetinu měsíčního úhrnu. Měsíc s největším počtem dní se srážkou je srpen a červenec (kolem 20 dnů), měsíc s nejmenším počtem dnů se srážkami duben (13 dnů). Nejdelší trvání období s výskytem srážky během jednoho dne je v zimě (kolem 50 \%), nejkratší v červenci (35\%). V denním chodu je patrné maximum srážek v podvečer (kolem 18. hodiny) a minimum dopoledne (kolem 10. hodiny).

\section{Literatura}

[1] VIZINA, A., KAŠPÁREK, L., KNĚŽEK, M. aj. Vodníbilance v podmínkách klimatické změny v povodíhorní Metuje. Praha: Výzkumný ústav vodohospodáŕský T. G. Masaryka, 2009, 126 s. ISBN 978-80-85900-94-1.

[2] ŠKÁCHOVÁ, H. a ŽÁK, M. Vánoční obleva v Česku - fakt nebo mýtus? Meteorologické zprávy, 2009, roč. 62, Č. 6, s. 187-199. ISSN 0026-1173.

[3] TREML, P. Vymezení období největšího růstu a největšího poklesu teploty vzduchu a vody metodou součtových řad. Meteorologickézprávy, 2010, roč. 63, č. 2, s. 52-56. ISSN 0026-1173.

[4] TREML, P. Extrémy v teplotě vzduchu a vody - období výskytu a jejich typizace vzhledem k největšímu vzestupu a poklesu teploty. Meteorologické zprávy, 2010, roč. 63, č. 4, s. 108-116. ISSN 0026-1173.

[5] TOLASZ, R. Změny ročního chodu srážek v České republice od roku 1961. Meteorologické zprávy, 2013, roč. 66, č. 4, s. 104-109. ISSN 0026-1173.

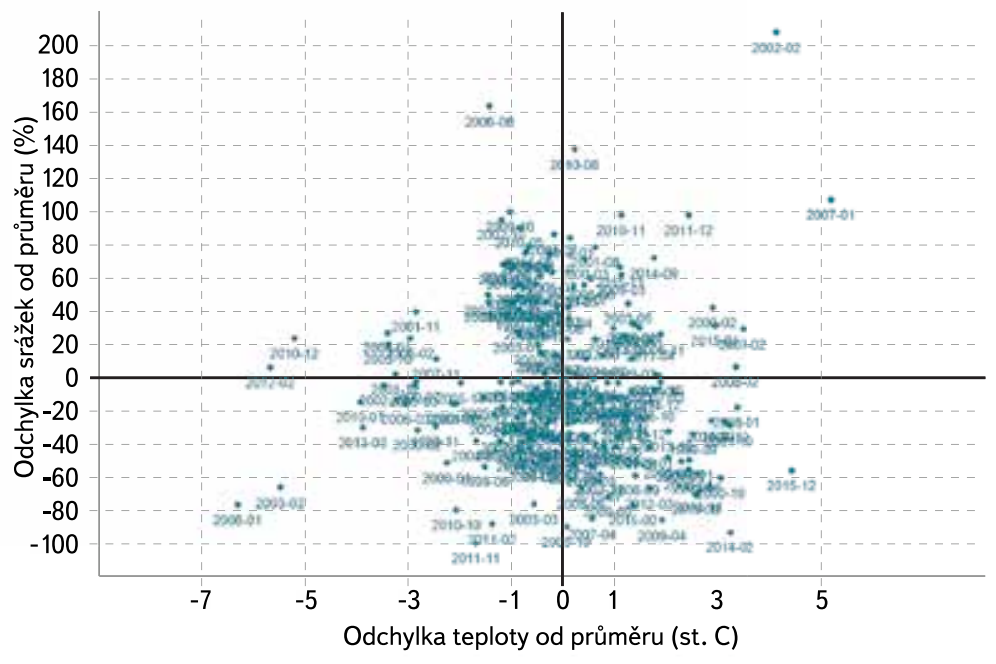

b) Srovnání odchylek teplot oproti odchylkám srážek v témže měsíci (tzn. uvažován průměrný roční chod srážek)

\section{Autor}

Mgr. Pavel Treml

凶pavel_treml@vuv.cz

Výzkumný ústav vodohospodářský T. G. Masaryka, v. v. i.

Př́spěvek prošel lektorským řizením.

\section{AIR TEMPERATURE AND PRECIPITATION ON THE METEOROLOGICAL STATION BUČNICE IN THE UPPER METUJE CATCHMENT \\ TREML, P.}

TGM Water Research Institute, p. r. i.

Keywords: air temperature - precipitation - daily temperature distribution - annual temperature distribution daily precipitation distribution - annual precipitation distribution - mass curve method - Bučnice

The paper deals with the analysis of time series of air temperature and precipitation at the meteorological station Bučnice in eastern Bohemia, which is operated by the TGM Water Research Institute. The annual and daily distributions of both variables were assessed, including the analysis of trends. Different types of air temperature extremes were defined based on the way of growth. 